\title{
The Kansei Design Characteristics towards Learning Style
}

\author{
Haeryip Sihombing, M. Y. Yuhazri, S. H. Yahaya, and Fevi Syaifoelida \\ Fakulti Kejuruteraan Pembuatan, Universiti Teknikal Malaysia Melaka (UTeM), Hang Tuah Jaya, 76100 Melaka, Malaysia \\ Correspondence should be addressed to Haeryip Sihombing; haery@australia.edu
}

Received 11 December 2012; Revised 5 April 2013; Accepted 9 April 2013

Academic Editor: Khoa Le

Copyright (C) 2013 Haeryip Sihombing et al. This is an open access article distributed under the Creative Commons Attribution License, which permits unrestricted use, distribution, and reproduction in any medium, provided the original work is properly cited.

\begin{abstract}
The individuals possess unique ways of how they learn. Based on this perspective, each of individuals will approach the general learning experiences in a personal and individualized way related to his/her performance and behavior. This study is to analyze the characteristics of product design using Kansei Engineering approach towards the student learning style based on Felder and Soloman's theory. Using the 8 (eight) spectacles designs proposed comparing the emotional feeling towards design of product, the study involved 100 students who are using spectacles as the respondents. Focusing on the perception and input dimensions of the Felder-Soloman learning styles comprised in 22 questions and the Crane cognitive alert styles in 9 questions, the result of study shows that the students who are using spectacles are dominated by "the visual" type of Felder-Soloman learning styles. In addition, based on the using of Kansei Engineering, this study also found that the respondents tend to interpret the rimless design of spectacles as "fragile," "unattractive," "old-fashion" product, while the design with thicker frame as "durable," "attractive," cool," "ergonomic" product. In this study, there are also the significant correlations proved against the preferences of product design based on quality affective (Kansei Engineering) using learning styles and cognitive alert styles.
\end{abstract}

\section{Introduction}

The different ways on how to approach and process the information (as the response to environments) may affect individuals' personalities and abilities to handle the various tasks $[1,2]$. This is a reason of why each of us possesses unique ways to learn something as a process of cognitive development [3]. Specifically, in the case of the applying of a single uniform approach refers to the similarities structure of the general learning experiences in the curriculum. In facts, the approach to such application, however, could not be effectively applied to the necessities in changing and improving the students' abilities to solve the multitude of problems. Also, in the context of how to facilitate and utilize several teaching methods and techniques, whereas the learners possess many style characteristics caused by their learnt in differently [4]. First, this due to the researchers tend to grouping the learners into categories in which they will theoretically and in its application sometimes (unintentionally) slip into the contradictions that confusing the majority [5]. Second, based on the assumption that stood on the growing evidences of people holding beliefs on how they learn to manage their owned learning and teaching others, so that it will drive the instructors to decide whether and how or not to modify certain aspects of the course $[6,7]$.

Taking on the views of student learning style against aforementioned problems, the first concern in this perspective is to the students' performance toward the behavior background. On this ground, the learning style is as the student preferences to the thinking, relating to others and particular types of classroom environments and experiences as well as the different levels of motivation and attitudes [9, 10]. The second concern is to an important issue of the higher education institutions and their management pertinent to the improvement efforts of teaching delivered. According to Pashler et al. [6], the beliefs of the learning-style assessments were useful in this educational context is apparently to be just a belief.

Based on this reason, according to the perspectives of learning behavior, Choi and Sardar [11] argued that the individuals are, in fact, different. They were constructed and associated with the preferences of verbal or visual information forms as the picture of the perceptual abilities of how the individuals obtain the information [12]. Thus, 
the preferences of each student to the general learning experiences, in accordance with the specific cognitive abilities that play a significant role in the students' development of the teaching and learning process carried out, should be on the approach in a personal and individualized way.

In addition, due to none of the teaching strategies, methods, or techniques employed for all students are successfully implementing in every situation-on how the way a student begins to concentrate on, process, internalize, and remember new and difficult academic information [4] - the approach taken needs to be reconstructed according to how the students prefer taking the process of information. For this reason, Dunn and Griggs [13] view about on how they are seeing and hearing, reflecting and acting, reasoning logically and intuitively, and analyzing and visualizing in different ways. Actually, the approach to learning can be briefly described as a function of student's learning orientation, and perceptions pertinent to the task requirements, where the learning task perceptions are, in turn, influenced by the context of learning (i.e., curriculum, teaching processes, and assessment methods) [14]. For instance, Mariani [15] stated the personal ways to tackle tasks in the classroom that perhaps are more important than a fixed set of strategies as part of a syllabus. Pask [16] underlined a possibility to teach students more effectively in their learning by applying the nontechnical manner that is also suitable for use in a classroom.

Hence, the model and formulation designed for capturing the learning style of the most important differences among students should be, therefore, built over a good foundation in formulating a teaching approach. This is as argued by Heenaye et al. [17] that the learning style is a concept of psychology about how the way individuals choose the process to the new information and adopting the strategies for effective learning. In this point of view, the different learning styles that depict the students choice on how they consume and process information, as well as different strengths through an integral feature of cognitive, affective, and psychological behaviors are the indicators of how students view, interact with, and react to the learning environment [10, 18]. Glass and Muthu [19] specified these features integration based on personality differences, perceptual factors, and the nature of memory from psychology, environmental influences from the sociological perspective, together with the concerns of the educational practitioner.

Based on the aforementioned reason, the focus of this study is on the learning styles of students that play significant roles in their development, such as verbal abilities, visual imagery, and spatial abilities. In terms of the visualizerverbalizer dimension of cognitive style and learning preferences to determine the priority of design proposed and what is the cognitive style behind their decisions [20], Kansei Engineering (KE) as the articulation of the product design characteristic is used as the foundation to the dimension of cognitive style. The reason of using $\mathrm{KE}$ method due to this method is fundamentally built on emotional feelings. KE method transforms the image into verbal expression referring to semantic characteristics as the information the visualizers and verbalizers in articulating their information preferences based on the pictures and words.
In this study, the proposed design is spectacle frame or eyeglass. By articulating the design into KE method using the pairwise scale of semantic differential questions that corresponds to the priorities and the preferences criteria, Bernasconi et al. [21] proposed the analysis structure of Saaty's AHP (analysis hierarchical process) method against the objectives for decision weights of alternatives presented.

\section{Literature Review}

The index of learning styles (ILS) is an instrument designed to assess the four-dimension preferences of the Felder and Silverman learning styles model, such as sensing, visual, active, and sequential. Since the focus of study is on the spectacles user, the learning style dimension concerned in this study is between the input characteristic, that is, visual versus verbal and the perception characteristic, which is sensing versus intuitive. (Table 1). First, for the perception dimension of learning styles, the sensing type represents the characteristics of cognitive attributes such as concrete, practical, and oriented toward facts and procedures. While the intuitive type preference is to the characteristics such as conceptual, innovative, and orientated toward theories and underlying meanings. Second, for the input dimension, the visual type of learning style preference is to the visual representations or images such as pictures, diagrams, and flow charts, while the verbal type preferences is to the written and spoken explanations.

In this study, the application of Kansei Engineering approach is to interpret the impression of somebody based on a certain artifact, environment, or situation using all their senses of sight, hearing, feeling, smell, and taste as well as their recognition [22]. From this point of view, Kansei Engineering is a technology that translates human feelings into a real live product. The meaning of "Kansei" is the psychological feelings and needs in mind, that are generally referred to sensitivity, sensibility, feeling, and emotion. Lee et al. [23] stated that Kansei is a Japanese word refers to the customers' psychological impressions or feelings about a product. It may be evoked by the product form, style, colour, function, price, and so forth and affected by consumers' emotions and personal senses of values. According to Wei et al. [24], Kansei Engineering is as an ergonomic methodology and design strategies for affective design to satisfy the consumer's psychological feelings. Briefly, it is a method to produce a product that fulfills the need based on the thought of their customers.

While to make the decision by seeking for the priorities and/or preferences, in this context is to process the Kansei results, the application of AHP (analytical hierarchy process) technique developed by Thomas Saaty in the 1970s for a decision-making system is employed to determine the preferences of the characteristic design and the product design proposed. Using a matrix model, AHP helps in determining the priorities of the criteria by pairwise comparison analysis of each criterion. This method is a framework for effective decision making towards complex issues. They simplify and accelerate the decision making process, that is, solve the problem into parts; arrange parts or variables in a hierarchy, 
TABLE 1: The index of learning style survey [8].

\begin{tabular}{|c|c|}
\hline & Perception \\
\hline Sensing learners & Intuitive learners \\
\hline (i) Like to learn facts & (i) Prefer to discover new ideas and connections \\
\hline (ii) Like to use established methods to solve problems & (ii) Like abstract problems \\
\hline $\begin{array}{l}\text { (iii) Resent being "thrown curves" (i.e., being tested on } \\
\text { something that has not been "covered") }\end{array}$ & (iii) Prefer to work quickly \\
\hline (iv) Are patient with work details and are good at memorizing & (iv) Do not like to memorize or do routine calculations \\
\hline (v) Like hands-on work & $\begin{array}{l}\text { (v) Should try to discipline themselves to check work to } \\
\text { make sure that careless mistakes have not been made }\end{array}$ \\
\hline \multicolumn{2}{|l|}{$\begin{array}{l}\text { (vi) Like learning things that have a direct connection to the } \\
\text { "real world" }\end{array}$} \\
\hline \multicolumn{2}{|l|}{ (vii) Should ask for specific examples when the task is unclear } \\
\hline & Input \\
\hline Visual learners & Verbal learners \\
\hline $\begin{array}{l}\text { (i) Remember what they see-timelines, demonstrations, } \\
\text { and flowcharts }\end{array}$ & (i) Prefer written or spoken instructions \\
\hline (ii) Create timelines for projects, papers, and tests & (ii) Should write summaries of tasks in their own words \\
\hline (iii) Color code tasks & (iii) Should try to work in groups or with a partner whenever possible \\
\hline
\end{tabular}

members numerical value on subjective judgment about the importance of each variable, and synthesize a variety of considerations to determine the variables that have the highest priority; and act to influence the outcome of the situation.

Here, AHP helps to solve complex problems by structuring a hierarchy of criteria, interested parties, with interesting results and considerations for developing weights or priorities. The method incorporates the strength of feeling and logic concerned about the issues and then synthesizes a diverse range of considerations into results that matched estimates, as we intuitively presented to the consideration has been made [25].

In educational environment, since it reveals in detail a student's thoughts, Drake [26] stated that AHP makes the selection process very transparent. This is as what was also found by Lee et al. [27] when it is used to analyse the KM platforms for elementary school students.

Below is an equation for a symmetrical and reciprocal for pairwise comparison in AHP approach based on Kansei words. Matrix symmetrical and reciprocal for pairwise comparisons-AHP:

$$
\left[\begin{array}{ccc}
\frac{X_{i}}{X_{i}} & \cdots & \frac{X_{n}}{X_{i}} \\
\vdots & \cdots & \vdots \\
\frac{X_{i}}{X_{n}} & \cdots & \frac{X_{n}}{X_{n}}
\end{array}\right]=\left[\begin{array}{l}
\left(\left[\frac{X_{i}}{X_{i}}\right] \times\left[\frac{X_{i+1}}{X_{i}}\right] \times \cdots\left[\frac{X_{n}}{X_{i}}\right]\right)^{1 / n} \\
\left(\left[\frac{X_{i}}{X_{n}}\right] \times\left[\frac{X_{i+1}}{X_{n}}\right] \times \cdots\left[\frac{X_{n}}{X_{n}}\right]\right)^{1 / n}
\end{array}\right]
$$

where $X$ is the Kansei words value based on semantic differential and $i$ is the number of Kansei words.

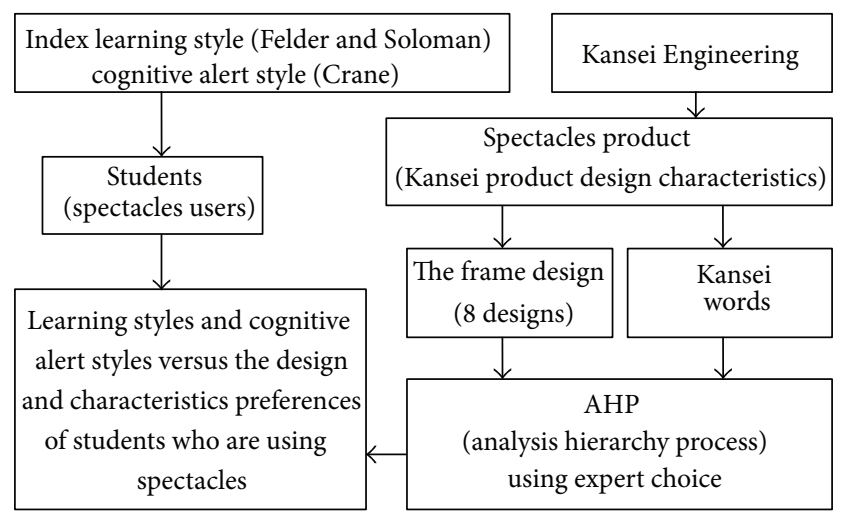

FIGURE 1: Framework of study.

\section{Methodology}

In this study, the 100 samples taken were from manufacturing engineering students and were quantitatively manipulated for analysis in the statistical format using SPSS. The assessment instruments used in the study is the questionnaires developed that consists of index of learning style [8] plus cognitive alert style [20] versus Kansei Engineering of product design characteristics using semantic differential (Figure 1). Set inquired about the index of learning style (ILS) comprises 22 items questions of the perception (sensing/intuitive learners) and input (visual/verbal learners) dimensions, while Cognitive Alert Style comprises 9 items (Appendix). All of the data taken were then descriptively analyzed based on correlation relationships.

Figure 2 shows the variant characteristics of the spectacles frame design, ranged from full frame design to rimless design ( 1 to 4 as well as 5 to 8 ). Specifically, the frame designs nos. 5 to 


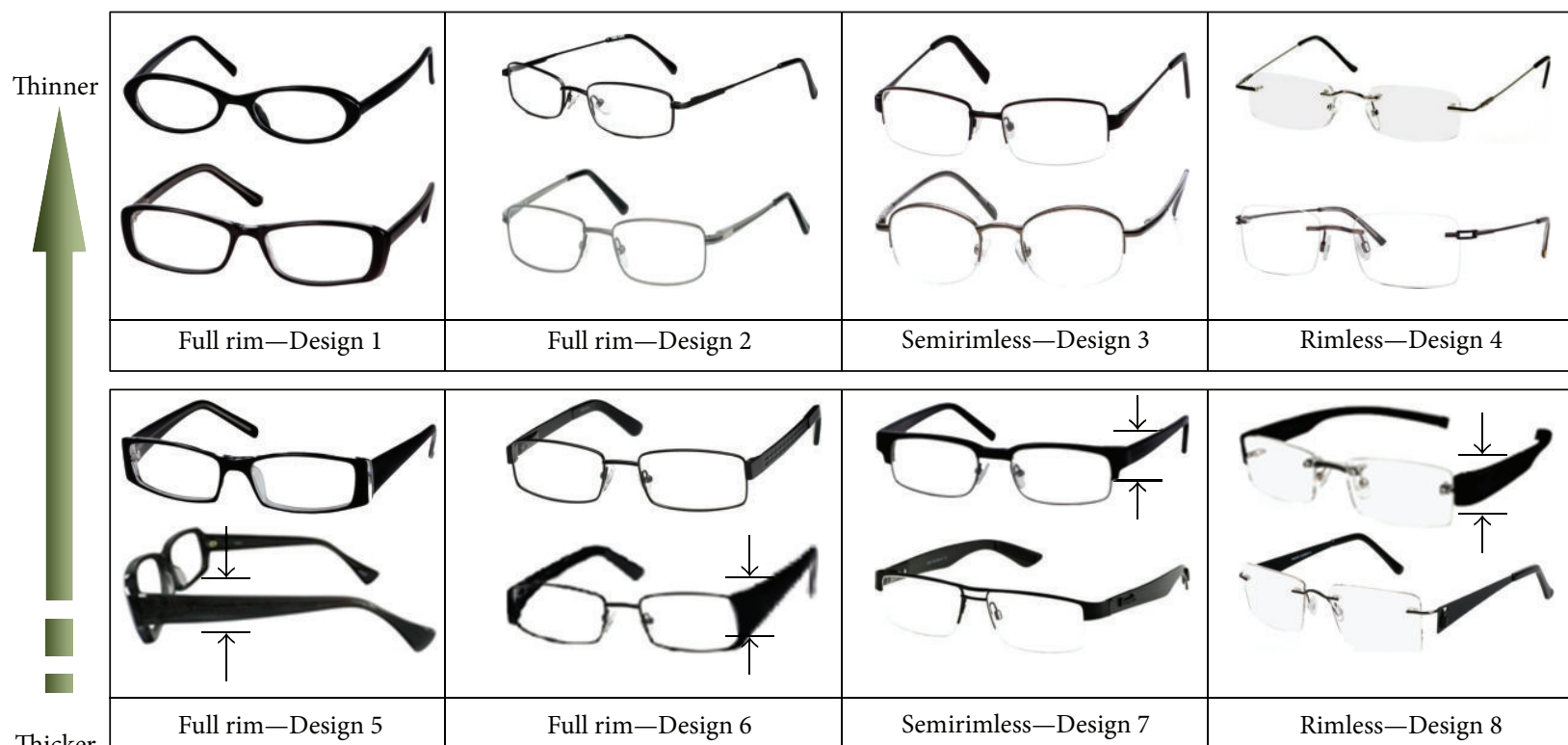

Full rim

$\square$

Rimless

Figure 2: Variant design of spectacles.

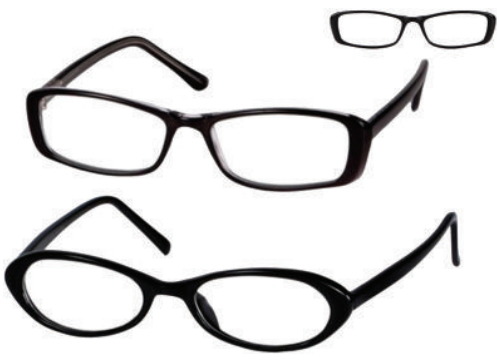

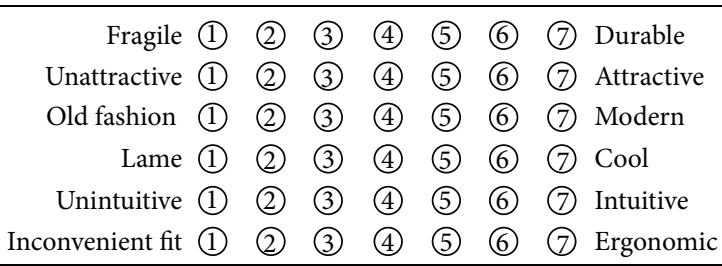

How much do you like/prefer this frame design?

Dislike (1) (2) (3) (4) (5) (6) (7) Like

FIGURE 3: Kansei words and design preferences (sample).

8 that are characteristically made with solid, compact, wide, and thick rim, while the Designs nos. 1 to 4 are constructed with less solid, more slim, and thinner rim. At the end of the $x$-axis, the designs nos. 4 and 8 represent the rimless design.

Figure 3 shows an example of Kansei words used with the semantic differential as the articulation of design characteristics in terms of emotional or quality affective. In order to capture what the customer feelings, this study stands on the assumption with the following hyphothesis:

$\mathrm{H}_{0}=$ there is no significant correlation between the preferences of product design based on quality affective (using Kansei Engineering) against the learning styles, specifically on "verbal versus visual" and "sensing versus intuitive" dimensions $(P<0.05)$.

$\mathrm{H}_{1}=$ there is significant correlation between the preferences of product design based on quality affective (using Kansei Engineering) against the learning styles, specifically on "verbal versus visual" and "sensing versus intuitive" dimensions $(P<0.05)$.

Here, in order to determine the design preferences based on AHP calculation, the Expert Choice software is used to process the qualitative data based on the matrix $8 \times 8$ of the design preferences and the matrix $6 \times 6$ of the Kansei words in each design proposed (see Figures 2 and 3 ).

\section{Result and Discussion}

4.1. The Design Frame Preferences. From 100 respondents which answer the questionnaires related to the 8 designs proposed towards the Kansei words, such as "fragile versus durable" (F/D), "unattractive versus attractive" (U/A), "old fashion versus modern" (O/M), "lame versus cool" $(\mathrm{L} / \mathrm{C})$, "unintuitive versus intuitive" (U/I), "inconvenient versus ergonomic" (I/E), and the frame design preferences ("dislike versus like") are the following.

(a) Table 2 shows the most preferred designs, which are Designs nos. 7 and 5, while Design no. 2 is the less preferred design.

(b) Based on data of Kansei words toward the spectacles designs proposed (Table 3), the results of AHP calculation using the Expert Choice software (Figure 4) show that the highest value of Kansei word is on "ergonomics-inconvenient" (17.2\%) and the highest 
TABLE 2: Kansei frame design preference results (based on dislike versus like).

\begin{tabular}{|c|c|c|c|c|c|c|c|c|c|}
\hline Answer & Design-1 & Design-2 & Design-3 & Design-4 & Design-5 & Design-6 & Design-7 & Design-8 & \\
\hline 1 & 10 & 32 & 13 & 27 & 2 & 2 & 2 & 6 & $\begin{array}{l}\text { Design-1 } \\
40\end{array}$ \\
\hline 2 & 10 & 26 & 12 & 18 & 0 & 6 & 1 & 6 & Design-8 \\
\hline 3 & 16 & 15 & 18 & 17 & 4 & 20 & 12 & 14 & Design-3 \\
\hline 4 & 15 & 12 & 26 & 20 & 11 & 19 & 25 & 21 & \\
\hline 5 & 26 & 11 & 17 & 10 & 28 & 28 & 32 & 17 & Design-6 \\
\hline 6 & 15 & 2 & 13 & 6 & 31 & 17 & 20 & 21 & $\begin{array}{l}\text { Design-5 } \\
-3 \stackrel{5}{-} 5\end{array}$ \\
\hline 7 & 8 & 2 & 1 & 2 & 24 & 8 & 8 & 15 & $-4-6$ \\
\hline
\end{tabular}

TABLE 3: The dominant of Kansei words towards the 8 design proposed using AHP.

\begin{tabular}{lccccccc}
\hline \multirow{2}{*}{ Design } & \multicolumn{7}{c}{ Kansei words } \\
& F/D & U/A & O/M & L/C & U/I & I/E & Like \\
\hline 1 & 5.05 & 4.26 & 4.28 & 4.32 & 4.4 & 4.62 & 4.14 \\
2 & 2.93 & 2.79 & 2.64 & 2.77 & 2.9 & 3.2 & 2.58 \\
3 & 3.81 & 4.07 & 3.92 & 3.88 & 3.86 & 4.09 & 3.65 \\
4 & 2.77 & 3.3 & 3.26 & 3.2 & 3.41 & 3.48 & 2.94 \\
5 & 5.57 & 5.42 & 5.43 & 5.31 & 5.21 & 5.39 & 5.52 \\
6 & 4.52 & 4.49 & 4.55 & 4.43 & 4.45 & 4.65 & 4.48 \\
7 & 4.8 & 4.85 & 4.77 & 4.7 & 4.71 & 4.87 & 4.76 \\
8 & 3.72 & 4.64 & 4.68 & 4.62 & 4.49 & 4.53 & 4.6 \\
\hline
\end{tabular}

preferences of the spectacle design proposed is to Design no. 5 (16\%).

(c) Table 4 shows the distribution of respondents' answers toward the 8 designs proposed in Figure 2. Through the spider web charts given (Figure 5), we can identify the following.

(1) The $x$-axis shows the width of frame that is articulated by the Kansei word "fragile versus durable" (F/D). Specifically to Design no. 4, mostly the respondents answered with value of 1 rather than Design no. 8 since the width of the frame/rim for the proposed Design no. 4 is thinner and rimless. This is also shown for the proposed Designs nos. 2 and 3 versus the proposed Designs nos. 4 and 5, respectively. However, they change when the width or thickness of the frame had already been bold enough. This is shown in Design no. 1 versus Design no. 5, where the value of "fragile" versus "durable" on the proposed Designs nos. 1 and 5 were 6 and 5 , respectively. This means that they are articulated as "durable." This is also shown in Figure 5, where mostly the answer of the respondents is a value of 5 for the proposed Designs nos. 5 and 7.

(2) The $y$-axis shows that the bold rim/frame also gives influence to the attractiveness of spectacles. Although it is not dominant, Designs

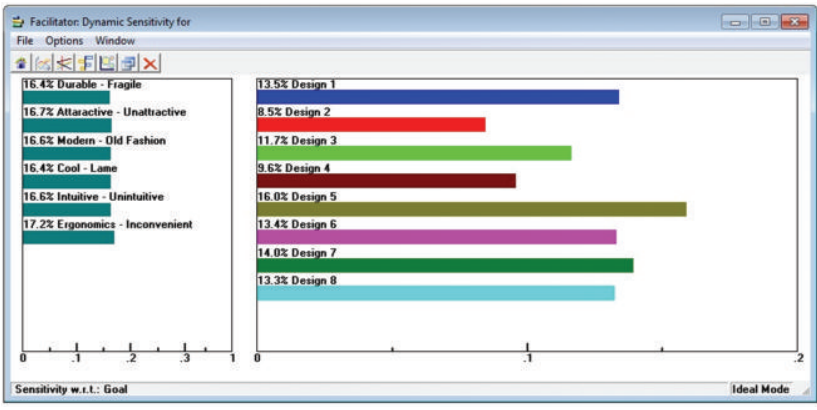

(a)

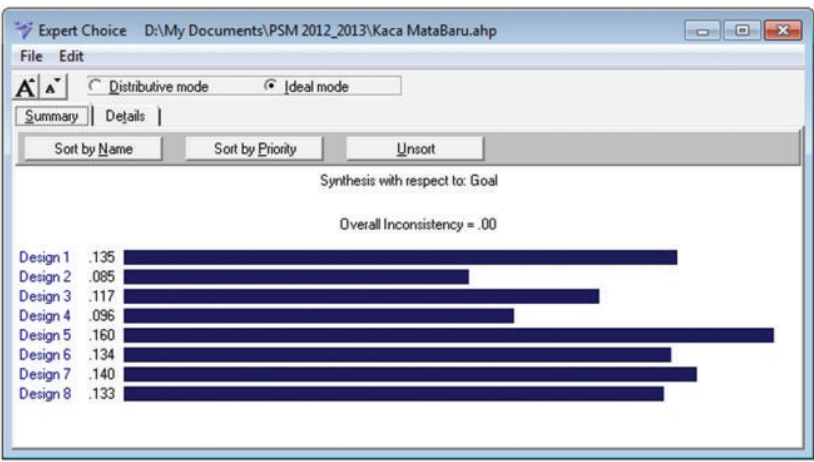

(b)

FIgURE 4: The dominant Kansei Words and the FRAME design.

nos. 5 until 8 show that mostly the respondents answer with value of 4 (neutral). This is also shown in Design no. 1 compared to Designs nos. 2 till 4, where they are mostly having value below than 4 . (They are tended to be articulated as "unattractive"). Figure 5 shows the proposed Designs nos. 2 and 3, where mostly the respondents answer with value of 2 and 4 .

(3) Towards Kansei word "old fashion versus modern," mostly the respondents answer to Design no. 4 with value of 2 (tends to be "old fashion"). This is opposite condition compared to Designs nos. 8 and no. 4 , that have the value of 6 (tends to be articulated as "modern"). Figure 6 shows that Design no. 6 has the most value of 5 for "modern." 
TABLE 4: The respondents' answers to the designs proposed.

\begin{tabular}{|c|c|c|c|c|c|c|}
\hline & $\mathrm{F} / \mathrm{D}$ & $\mathrm{U} / \mathrm{A}$ & $\mathrm{O} / \mathrm{M}$ & $\mathrm{L} / \mathrm{C}$ & $\mathrm{U} / \mathrm{I}$ & $\mathrm{I} / \mathrm{E}$ \\
\hline & \multicolumn{6}{|c|}{ Design-1 } \\
\hline 1 & 4 & 5 & 7 & 6 & 5 & 3 \\
\hline 2 & 3 & 8 & 8 & 5 & 3 & 2 \\
\hline 3 & 9 & 13 & 16 & 16 & 14 & 16 \\
\hline 4 & 16 & 28 & 22 & 25 & 28 & 23 \\
\hline 5 & 22 & 28 & 22 & 24 & 29 & 29 \\
\hline 6 & 28 & 12 & 16 & 20 & 17 & 19 \\
\hline \multirow[t]{2}{*}{7} & 18 & 6 & 9 & 4 & 4 & 8 \\
\hline & \multicolumn{6}{|c|}{ Design-2 } \\
\hline 1 & 18 & 22 & 26 & 18 & 19 & 16 \\
\hline 2 & 23 & 29 & 29 & 30 & 24 & 21 \\
\hline 3 & 30 & 21 & 19 & 28 & 25 & 23 \\
\hline 4 & 15 & 13 & 14 & 11 & 17 & 20 \\
\hline 5 & 8 & 9 & 7 & 9 & 11 & 12 \\
\hline 6 & 3 & 3 & 3 & 2 & 3 & 3 \\
\hline \multirow[t]{2}{*}{7} & 3 & 3 & 2 & 2 & 1 & 5 \\
\hline & \multicolumn{6}{|c|}{ Design-3 } \\
\hline 1 & 8 & 4 & 4 & 5 & 5 & 6 \\
\hline 2 & 8 & 12 & 13 & 13 & 12 & 6 \\
\hline 3 & 24 & 18 & 16 & 16 & 14 & 18 \\
\hline 4 & 29 & 28 & 31 & 34 & 37 & 31 \\
\hline 5 & 20 & 18 & 26 & 20 & 25 & 23 \\
\hline 6 & 8 & 17 & 10 & 11 & 7 & 14 \\
\hline \multirow[t]{2}{*}{7} & 3 & 3 & 0 & 1 & 0 & 2 \\
\hline & \multicolumn{6}{|c|}{ Design-4 } \\
\hline 1 & 30 & 19 & 20 & 19 & 20 & 15 \\
\hline 2 & 18 & 19 & 13 & 15 & 11 & 16 \\
\hline 3 & 18 & 15 & 22 & 24 & 13 & 18 \\
\hline 4 & 18 & 22 & 22 & 20 & 30 & 27 \\
\hline 5 & 13 & 14 & 16 & 15 & 19 & 11 \\
\hline 6 & 1 & 7 & 3 & 5 & 4 & 7 \\
\hline \multirow[t]{2}{*}{7} & 2 & 4 & 4 & 2 & 3 & 6 \\
\hline & \multicolumn{6}{|c|}{ Design-5 } \\
\hline 1 & 2 & 2 & 3 & 2 & 2 & 3 \\
\hline 2 & 2 & 0 & 0 & 2 & 2 & 0 \\
\hline 3 & 0 & 5 & 5 & 4 & 1 & 1 \\
\hline 4 & 4 & 11 & 13 & 11 & 20 & 18 \\
\hline 5 & 41 & 32 & 26 & 34 & 34 & 29 \\
\hline 6 & 27 & 29 & 28 & 30 & 25 & 27 \\
\hline \multirow[t]{2}{*}{7} & 24 & 21 & 25 & 17 & 16 & 22 \\
\hline & \multicolumn{6}{|c|}{ Design-6 } \\
\hline 1 & 2 & 3 & 4 & 5 & 2 & 3 \\
\hline 2 & 9 & 6 & 6 & 8 & 7 & 6 \\
\hline 3 & 11 & 10 & 13 & 11 & 11 & 13 \\
\hline 4 & 30 & 30 & 21 & 25 & 34 & 19 \\
\hline 5 & 18 & 29 & 30 & 24 & 23 & 30 \\
\hline 6 & 21 & 15 & 16 & 20 & 16 & 18 \\
\hline 7 & 9 & 7 & 10 & 7 & 7 & 11 \\
\hline
\end{tabular}

TABLE 4: Continued.

\begin{tabular}{ccccccc}
\hline & F/D & U/A & O/M & L/C & U/I & I/E \\
\hline 1 & 2 & 3 & 2 & 2 & 2 & 2 \\
2 & 4 & 2 & 3 & 3 & 2 & 2 \\
3 & 10 & 10 & 15 & 16 & 14 & 12 \\
4 & 18 & 18 & 21 & 18 & 23 & 20 \\
5 & 38 & 32 & 25 & 31 & 32 & 31 \\
6 & 18 & 29 & 23 & 23 & 18 & 21 \\
7 & 10 & 6 & 11 & 7 & 9 & 12 \\
\hline & & \multicolumn{5}{c}{ Design-7 } \\
\hline 1 & 14 & 3 & 4 & 4 & 2 & 2 \\
2 & 15 & 11 & 8 & 9 & 9 & 7 \\
3 & 16 & 7 & 7 & 9 & 12 & 14 \\
4 & 19 & 20 & 23 & 21 & 27 & 25 \\
5 & 18 & 27 & 22 & 25 & 24 & 26 \\
6 & 12 & 21 & 27 & 20 & 17 & 17 \\
7 & 6 & 11 & 9 & 12 & 9 & 9 \\
\hline
\end{tabular}

TABLE 5: Correlation value versus correlation level.

\begin{tabular}{lc}
\hline Correlation value & Correlation level \\
\hline $0.00-0.20$ & Weak \\
$0.21-0.40$ & Low \\
$0.41-0.60$ & Moderate \\
$0.61-0.80$ & Strong \\
$0.81-1.00$ & Very strong \\
\hline
\end{tabular}

TABLE 6: The learning style types.

\begin{tabular}{lcc}
\hline Learning style type & Qty & Total \\
\hline Sensing & 33 & \\
Fairly & 13 & $\mathbf{4 7}$ \\
Moderate & 1 & \\
$\quad$ Strong & & \\
\hline Intuitive & 33 & $\mathbf{5 3}$ \\
$\quad$ Fairly & 14 & \\
Moderate & 6 & $\mathbf{8 7}$ \\
$\quad$ Strong & & \\
\hline Visual & 18 & \\
Fairly & 29 & $\mathbf{1 3}$ \\
Moderate & 40 & \\
$\quad$ Strong & & \\
\hline Verbal & 10 & \\
Fairly & 2 & \\
Moderate & 1 & \\
$\quad$ Strong & &
\end{tabular}

(4) Towards Kansei word "unintuitive versus intuitive," mostly the respondents answer to the proposed Designs nos. 5, 7, and 1 with value of 5 (Figure 6), while for the proposed Designs nos. 3 and 6 , the respondents mostly give the judgment with value of 4 . 
TABLE 7: The interrelationships of learning style dimension.

\begin{tabular}{lcccc}
\hline & \multicolumn{2}{c}{ Perception } & \multicolumn{2}{c}{ Input } \\
& Sensing & Intuitive & Visual & Verbal \\
\hline Sensing & 1 & $-0.743^{* *}$ & & \\
Intuitive & & 1 & & \\
Visual & & & 1 & $-0.715^{* *}$ \\
Verbal & & & & 1 \\
\hline
\end{tabular}

${ }^{*}$ Correlation is significant at the 0.05 level (2-tailed).

${ }^{* *}$ Correlation is significant at the 0.01 level (2-tailed).

(5) Towards Kansei word "inconvenient versus ergonomic," mostly the respondent answer with value of 5 for the proposed Designs nos. 5, 6, 7, and 1 (Figure 6), while for the proposed Design no. 3 , mostly the respondents judged with value of 4 .

(6) The respondents judged the proposed Designs nos. 7, 6, and 5 with value of 5 . This finding was also as calculated using Expert Choice software based on analytical hierarchy process (AHP) method (Figure 4). The less preference design is the proposed Design no. 2, due to being dominated with value of 1 (see Table 2 for a comparison).

4.2. The Correlation between Learning Style Dimensions and the Cognitive Alert Style. By using the correlation levels as shown in Table 5, the correlation between the learning styles of input and perception dimensions is as follows.

(a) The students learning styles are dominated with "intuitive" and "visual" types of learning styles (53 and 87 students, resp.) (Table 6). As a pair function aspect ("sensing versus intuitive" and "visual versus verbal") of learning styles dimension, it is known and proved that the learning styles for the "sensing versus intuitive" and "visual versus verbal" are having symmetrical construction, in which both of them have a negative value (-) (Table 7 ). This means that the learning styles dimensions of these two dimensions are supporting each other. The correlation between "sensing versus intuitive" and "visual versus verbal" is significant $(P<0.01)$ with strong reverse values $(-0.743$ and -0.715$)$. This finding proved that there is significant correlation existed on the dimension of learning styles for "sensing" to "intuitive" and "visual" to "verbal" as was proposed by Felder and Soloman.

(b) Based on the respondents characteristics (Table 7), the dominant of learning styles on the perception dimension are fairly "sensing" and fairly "intuitive" (33 students each) where the majority of them were on the "visual" type (moderate $=29$ and strong = 40). Table 8 shows that the "sensing-intuitive" learner type preferences are having correlation with Q8 (the common habit to the activities done), while the "visualverbal" learner type with Q5 (people's thinking of me as organized or unorganized person). The significant correlations among them were 0.226 and $-0.231(P<$ $0.05)$, respectively.

In detail, the "sensing-intuitive" (SI) learner type is related to the working existence (Q1) of what the respondents consider themselves (as realistic or innovative person) (SI1) and what they are likely to be considered in their work (as a person who is careful about the details of work or creative in doing the work) (SI6). This also explains what they do when taking a break (Q2) against how they are doing for long calculations: "Do they tend to repeat the steps and check the work carefully or they force themselves to check the work"? (SI11). On the other side, what he/she feel people to think about his or herself (unorganized and well organized person?) (Q5) related to how they appreciate someone else (SI9) (Table 9(a)).

The "visual-verbal" (VV) learner type (based on what the students prefer to get new information (VV2), to remember the teacher explanation (VV7) and data description (VV8) and the preferences of the entertainment types (VV10)) were related to what the students think about the time against their works (Q3), feel about people thinking of them as individuals; "organized or unorganized" (Q5), and how they do the job; "for variety or do not change it" (Q7). Most of them ("sensingintuitive" and "visual-verbal" learner type) were related to how the students feel about people what think to his or herself (unorganized and well-organized person?) (Q5).

Table 9(b) shows that "If I were a teacher, I would rather teach a course that deals with facts and real-life situations" (SI2), "I consider it higher praise to call someone imaginative" (SI9), "I prefer to get new information in pictures, diagrams, graphs, or maps" (VV2), and "For entertainment, I would rather watch television" (VV10) are having the highest numbers of students. All of them have the most numbers to how the students feel about what people think of them as a person (unorganized and well-organized person?) (Q5), that were 47, 38,54 , and 50 out of 100 students.

Based on the background of respondents (students who are spectacles users) (Table 10), we can find that 34 out 100 students have sunglass, and almost 50\% (46\%) have more than 1 spectacle. They are always using their spectacles at all times (73 out of 100), where 46 of them tend to change the way they do the job for variety rather than do not change it (Q7).

\subsection{The Correlation between Cognitive Alert Style} and Learning Style toward Product Design Characteristic (Kansei Engineering)

\subsubsection{Cognitive Alert Styles versus Product Design Characteristics}

(i) Table 11 shows that there is no significant correlation between cognitive alert styles and Designs nos. 1, 3, 7 , and 8 . It is noted that the correlation of cognitive alert styles towards Designs nos. 2, 4, 5, and 6 is significantly low based on the classification in Table 5 . The most numbers of correlation existed were for Design no. 2 (which have 4 values). They are related 
TABLE 8: Correlation between learning style (perception and input dimensions) and cognitive alert style.

\begin{tabular}{|c|c|c|c|c|c|c|c|c|c|}
\hline & Q1 & Q2 & Q3 & Q4 & Q5 & Q6 & Q7 & Q8 & Q9 \\
\hline Visual-Verbal VV & & & & & $0.226^{*}$ & & & & \\
\hline Sensing-Intuitive SS & & & & & & & & $-0.231^{* *}$ & \\
\hline
\end{tabular}

${ }^{*}$ Correlation is significant at the 0.05 level (2 tailed).

${ }^{* *}$ Correlation is significant at the 0.01 level ( 2 tailed).

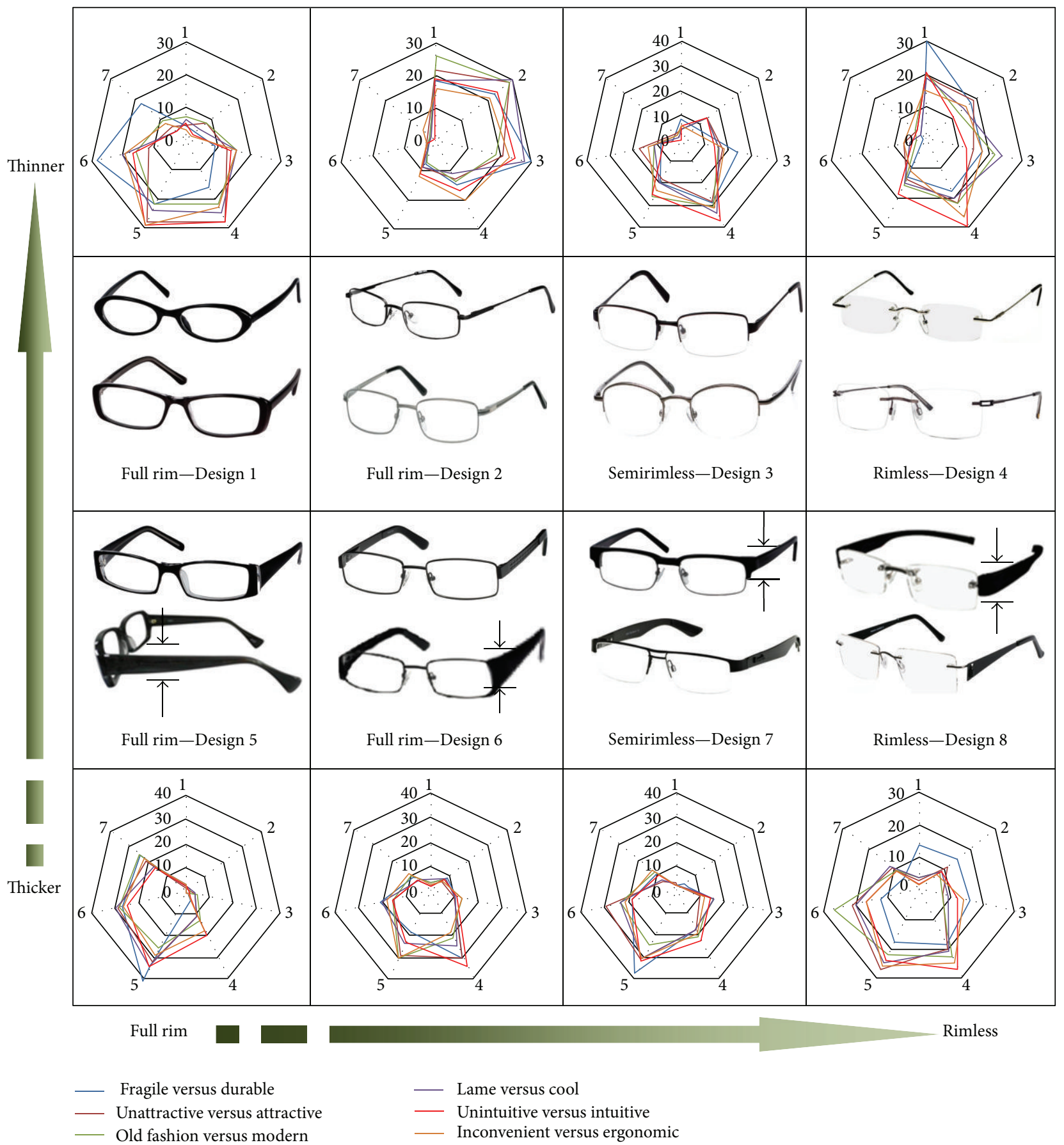

FIgURE 5: The Spider Web Chart mapping of the designs proposed based on Kansei words. 


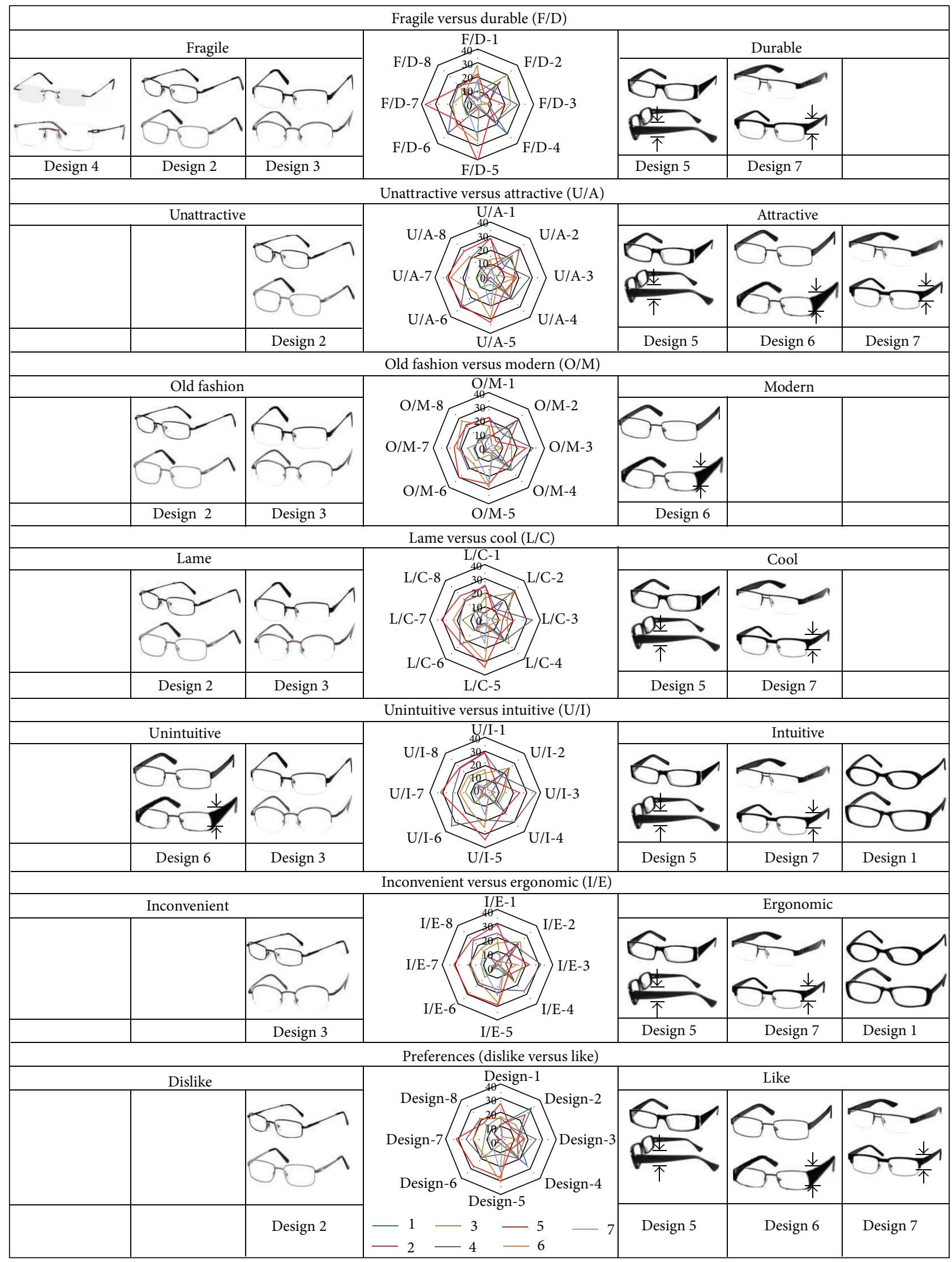

FIGURE 6: Location of the design preferences based on Kansei words. 
TABle 9: (a) Correlation between learning styles (perception and input dimensions) and cognitive alert styles. (b) Correlation between learning styles (SI2; SI9; VV2; VV10) and cognitive alert styles (Q5).

(a)

\begin{tabular}{|c|c|c|c|c|c|c|c|c|c|}
\hline Questions & Q1 & Q2 & Q3 & Q4 & Q5 & Q6 & Q7 & Q8 & Q9 \\
\hline Sensing-Intuitive 1 & $-0.197^{*}$ & & & & & & & & \\
\hline Sensing-Intuitive 2 & & & & & $0.202^{*}$ & & & & \\
\hline Sensing-Intuitive 3 & & & & & & & & & \\
\hline Sensing-Intuitive 4 & & & & & & & & & \\
\hline Sensing-Intuitive 5 & & & & & & & & & \\
\hline Sensing-Intuitive 6 & $-0.262^{* *}$ & & & & & & & & \\
\hline Sensing-Intuitive 7 & & & & & & & & & \\
\hline Sensing-Intuitive 8 & & & & & & & & & \\
\hline Sensing-Intuitive -9 & & & & & $-0.243^{*}$ & & & & \\
\hline Sensing-Intuitive 10 & & & & & & & & & \\
\hline Sensing-Intuitive 11 & & $-0.280^{* *}$ & & & & & & & \\
\hline Visual-Verbal 1 & & & & & & & & & \\
\hline Visual-Verbal 2 & & & & & $0.238^{*}$ & & & & \\
\hline Visual-Verbal 3 & & & & & & & & & \\
\hline Visual-Verbal 4 & & & & & & & & & \\
\hline Visual-Verbal 5 & & & & & & & & & \\
\hline Visual-Verbal 6 & & & & & & & & & \\
\hline Visual-Verbal 7 & & & & & & $0.228^{*}$ & & & \\
\hline Visual-Verbal 8 & & & $-0.237^{*}$ & & & & & & \\
\hline Visual-Verbal 9 & & & & & & & & & \\
\hline Visual-Verbal 10 & & & & & $0.202^{*}$ & & & & \\
\hline Visual-Verbal 11 & & & & & & & & & \\
\hline
\end{tabular}

(b)

\begin{tabular}{|c|c|c|c|}
\hline & \multicolumn{3}{|c|}{ Q5: other people think } \\
\hline & I'm unorganized & I organize things well & Total \\
\hline \multicolumn{4}{|l|}{ Sensing-Intuitive 2 (SI2) } \\
\hline \multicolumn{4}{|l|}{ If I were a teacher, I would rather teach a course } \\
\hline that deals with facts and real-life situations & 26 & 47 & 73 \\
\hline that deals with ideas and theories & 4 & 23 & 27 \\
\hline Total & 30 & 70 & 100 \\
\hline \multicolumn{4}{|l|}{ Sensing-Intuitive 9 (SI9) } \\
\hline \multicolumn{4}{|l|}{ I consider it higher praise to call someone } \\
\hline sensible & 6 & 32 & 38 \\
\hline imaginative & 24 & 38 & 62 \\
\hline Total & 30 & 70 & 100 \\
\hline \multicolumn{4}{|l|}{ Visual-Verbal 2 (VV2) } \\
\hline \multicolumn{4}{|l|}{ I prefer to get new information in } \\
\hline pictures, diagrams, graphs, or maps & 29 & 54 & 83 \\
\hline written directions or verbal information & 1 & 16 & 17 \\
\hline Total & 30 & 70 & 100 \\
\hline \multicolumn{4}{|l|}{ Visual-verbal 10 (VV10) } \\
\hline \multicolumn{4}{|l|}{ For entertainment, I would rather } \\
\hline watch television & 27 & 50 & 77 \\
\hline read a book & 3 & 20 & 23 \\
\hline Total & 30 & 70 & 100 \\
\hline
\end{tabular}

${ }^{*}$ Correlation is significant at the 0.05 level (2 tailed).

${ }^{* *}$ Correlation is significant at the 0.01 level ( 2 tailed). 
TABLE 10: Correlation between cognitive alert styles and students characteristics (spectacles users).

(a)

\begin{tabular}{|c|c|c|c|c|c|c|c|c|c|}
\hline & Q1 & Q2 & Q3 & Q4 & Q5 & Q6 & Q7 & Q8 & Q9 \\
\hline Gender & & & & & & $0.250^{*}$ & & & \\
\hline \multicolumn{10}{|l|}{ Power } \\
\hline Use & & & & & & & $0.265^{* *}$ & & \\
\hline \multicolumn{10}{|l|}{ Lens } \\
\hline First time & & & & & & & $0.198^{*}$ & & \\
\hline \multicolumn{10}{|l|}{ Last time } \\
\hline Quantity spec & & $0.265^{* *}$ & & & & & $-0.247^{*}$ & & \\
\hline Sunglass & $0.286^{* *}$ & $-0.197^{*}$ & & & $-0.240^{*}$ & & & & \\
\hline First preference & & & & & & & & & \\
\hline
\end{tabular}

(b)

\begin{tabular}{lccccc}
\hline Cognitive alert style-Q7 & Before elementary school & Elementary school & High school & University & Total \\
\hline I change the way I do for variety & 7 & 20 & 26 & 2 & 55 \\
When one way works well, I don't change it & 4 & 10 & 25 & 6 & 45 \\
\hline Total & 11 & 30 & 51 & 8 & 100 \\
\hline
\end{tabular}

(c)

\begin{tabular}{llcc}
\hline Cognitive alert style -Q7 & Yes & No & Total \\
\hline I change the way I do for variety & 46 & 9 & 55 \\
When one way works well, I don't change it & 27 & 18 & 45 \\
\hline Total & 73 & 27 & 100 \\
\hline
\end{tabular}

(d)

\begin{tabular}{lc}
\hline Having spectacle & Freq \\
\hline 1 & 54 \\
2 & 26 \\
3 & 20 \\
\hline Having sunglass & 34 \\
\hline
\end{tabular}

${ }^{*}$ Correlation is significant at the 0.05 level (2 tailed).

${ }^{*}$ Correlation is significant at the 0.01 level (2 tailed).

to what the students do if they take a break (Q4) and what is their habit if they are putting something (Q9).

(ii) Based on Kansei words, the pairwise of "unattractive versus attractive" and "old fashion versus modern" having the most numbers of significant correlation to cognitive alert style. This occurs in Designs nos. 2, 4, and 5. However, only Design no. 4 and positive significant correlation. Most students who confessed doing something important first and other things later (Q4) feel that Design no. 2 is mostly "lame," that is, 58 students (Table 12).

(iii) By using the approach that manipulates the answer data of semantic differential ranged with value of 1 to 7 as a pairwise question of the Kansei words into "low," "moderate or neutral," and "high" described in Table 13, the correlation of the 8 designs proposed that are articulated through Kansei words against the cognitive alert style is shown in Table 14.

(iv) The Kansei words "old fashion versus modern" and "inconvenient versus ergonomic" as the articulation of the 8 designs proposed do not have any correlation with cognitive alert style. Among the correlations of Kansei words against Cognitive alert style, the most numbers existed on "lame versus cool", that is, 5 values $(-.0199,-0.217,-0.259,-0.203$, and -0.220$)$. The significant correlation $(P<0.01)$ is related to the way students do the job (Q7), that is -0.259 . They articulated the proposed Design no. 5 "cool" rather than "lame" (47 students versus 4 students), especially for students who think that they are changing the way they do the job for variety (32 out of 100). Also, they tend to identify the proposed Design no. 5 as "cool" for the students who prefer to arrange objects to be centered and in line (34 out of 100). (Table 15).

\subsubsection{Learning Styles versus Product Design Characteristics}

(i) Table 16 shows there is no significant correlation between Felder-Soloman learning styles and the 8 spectacle designs proposed. It is noted that the most number of significant correlation of Felder-Soloman learning styles related to "sensing-intuitive" is to what 
TABLE 11: Correlation between design proposed toward cognitive alert style.

\begin{tabular}{|c|c|c|c|c|c|c|c|c|c|c|}
\hline Design & Kansei words & Q1 & Q2 & Q3 & Q4 & Q5 & Q6 & Q7 & Q8 & Q9 \\
\hline \multirow{6}{*}{ Design-1 } & 1-Fragile-Durable & & & & & & & & & \\
\hline & 1-Unattractive-Attractive & & & & & & & & & \\
\hline & 1-Old Fashion-Modern & & & & & & & & & \\
\hline & 1-Lame-Cool & & & & & & & & & \\
\hline & 1-Unintuitive-Intuitive & & & & & & & & & \\
\hline & 1-Inconvenient-Ergonomic & & & & & & & & & \\
\hline \multirow{6}{*}{ Design-2 } & 2-Fragile-Durable & & & & & & & & & \\
\hline & 2-Unattractive-Attractive & & & & & & & & & \\
\hline & 2-Old Fashion-Modern & & & & $-0.257^{* *}$ & & & & & \\
\hline & 2-Lame-Cool & & & & $-0.226^{*}$ & & & & & $-0.199^{*}$ \\
\hline & 2-Unintuitive-Intuitive & & & & & & & & & \\
\hline & 2-Inconvenient-Ergonomic & & & & $-0.234^{*}$ & & & & & \\
\hline \multirow{6}{*}{ Design-3 } & 3-Fragile-Durable & & & & & & & & & \\
\hline & 3-Unattractive-Attractive & & & & & & & & & \\
\hline & 3-Old Fashion-Modern & & & & & & & & & \\
\hline & 3-Lame-Cool & & & & & & & & & \\
\hline & 3-Unintuitive-Intuitive & & & & & & & & & \\
\hline & 3-Inconvenient-Ergonomic & & & & & & & & & \\
\hline \multirow{6}{*}{ Design-4 } & 4-Fragile-Durable & & & & & & & & & \\
\hline & 4-Unattractive-Attractive & & & & & & & & $0.230^{*}$ & \\
\hline & 4-Old Fashion-Modern & & & & & & & & $0.199^{*}$ & \\
\hline & 4-Lame-Cool & & & & & & & & & \\
\hline & 4-Unintuitive-Intuitive & & & & & & & & & \\
\hline & 4-Inconvenient-Ergonomic & & & & & & & & & \\
\hline \multirow{6}{*}{ Design-5 } & 5-Fragile-Durable & & & & & & & & & \\
\hline & 5-Unattractive-Attractive & & & & & & & $-0.222^{*}$ & & \\
\hline & 5-Old Fashion-Modern & & & & & & & $-0.209^{*}$ & & \\
\hline & 5-Lame-Cool & & & & & & & & & \\
\hline & 5-Unintuitive-Intuitive & & & & & & & & & \\
\hline & 5-Inconvenient-Ergonomic & & & & & & & & & \\
\hline \multirow{6}{*}{ Design-6 } & 6-Fragile-Durable & & & & & & & & $-0.197^{*}$ & \\
\hline & 6-Unattractive-Attractive & & & & & & & & & \\
\hline & 6-Old Fashion-Modern & & & & & & & & & \\
\hline & 6-Lame-Cool & & & & & & & & & \\
\hline & 6-Unintuitive-Intuitive & & & & & & & & & \\
\hline & 6-Inconvenient-Ergonomic & & & & & & & & & \\
\hline \multirow{6}{*}{ Design-7 } & 7-Fragile-Durable & & & & & & & & & \\
\hline & 7-Unattractive-Attractive & & & & & & & & & \\
\hline & 7-Old Fashion-Modern & & & & & & & & & \\
\hline & 7-Lame-Cool & & & & & & & & & \\
\hline & 7-Unintuitive-Intuitive & & & & & & & & & \\
\hline & 7-Inconvenient-Ergonomic & & & & & & & & & \\
\hline \multirow{6}{*}{ Design-8 } & 8-Fragile-Durable & & & & & & & & & \\
\hline & 8-Unattractive-Attractive & & & & & & & & & \\
\hline & 8-Old Fashion-Modern & & & & & & & & & \\
\hline & 8-Lame-Cool & & & & & & & & & \\
\hline & 8-Unintuitive-Intuitive & & & & & & & & & \\
\hline & 8-Inconvenient-Ergonomic & & & & & & & & & \\
\hline
\end{tabular}

${ }^{*}$ Correlation is significant at the 0.05 level ( 2 tailed).

${ }^{* *}$ Correlation is significant at the 0.01 level (2 tailed). 
TABLE 12: Correlation between Design no.2 toward Kansei Words

\begin{tabular}{|c|c|c|c|c|c|c|c|c|}
\hline \multirow{2}{*}{ 2-Old fashion-modern } & \multicolumn{8}{|c|}{ 2-Lame-cool } \\
\hline & Very lame & Lame & Less lame & Not cool & Less cool & Cool & Very cool & Total \\
\hline \multicolumn{9}{|c|}{ Q4-I do easy things first and save important things for later } \\
\hline Very old & 1 & 0 & 0 & 0 & 0 & & 0 & 1 \\
\hline Old & 0 & 6 & 2 & 0 & 0 & & 0 & 8 \\
\hline Less old & 0 & 0 & 3 & 1 & 0 & & 0 & 4 \\
\hline Not modern & 0 & 1 & 0 & 1 & 0 & & 0 & 2 \\
\hline Less modern & 0 & 0 & 0 & 1 & 3 & & 0 & 4 \\
\hline Very modern & 0 & 0 & 0 & 0 & 0 & & 2 & 2 \\
\hline Total & 1 & 7 & 5 & 3 & 3 & & 2 & 21 \\
\hline \multicolumn{9}{|c|}{ Q4-I do important things first and other things later } \\
\hline Very old & 16 & 6 & 3 & 0 & 0 & 0 & & 25 \\
\hline Old & 1 & 14 & 5 & 1 & 0 & 0 & & 21 \\
\hline Less old & 0 & 3 & 10 & 2 & 0 & 0 & & 15 \\
\hline Not modern & 0 & 0 & 5 & 5 & 2 & 0 & & 12 \\
\hline Less modern & 0 & 0 & 0 & 0 & 2 & 1 & & 3 \\
\hline Modern & 0 & 0 & 0 & 0 & 2 & 1 & & 3 \\
\hline Total & 17 & 23 & 23 & 8 & 6 & 2 & & 79 \\
\hline
\end{tabular}

TABLE 13: Classification of Kansei words pairwise question into low, moderate, and high.

\begin{tabular}{lcc}
\hline $\begin{array}{l}\text { Low } \\
\leq \text { Min }\end{array}$ & $\begin{array}{c}\text { Moderate (neutral) } \\
<\text { Mean }>\end{array}$ & $\begin{array}{c}\text { High } \\
\geq \text { Max }\end{array}$ \\
\hline Fragile & F-D & Durable \\
Unattractive & U-A & Attractive \\
Old fashion & O-M & Modern \\
Lame & L-C & Cool \\
Unintuitive & U-I & Intuitive \\
Inconvenient & I-E & Ergonomic \\
\hline
\end{tabular}

the students like on how the way of writers telling the story in the books (SI7), that is 9 values. Most of them were on the proposed Design no. 2. Also, the proposed Design no. 2 has the most significant correlation compared to other proposed design, that is, 7 values. Based on the significant correlation between "sensing-intuitive" the proposed Design no. $2(-0.288, P<0.01)$, there are 72 out of 100 students who identified Design no. 2 as "unattractive" (Table 17). Most of them are the students who identified themselves as the persons who like reading the book that say things in creative ways (58 students). For the correlation between the designs proposed and learning styles see Table 16.

(ii) Towards "visual-verbal" learning style, there is the proposed Design no. 6 having the most numbers of significant correlations (9 values). Most of them related to the entertainment preferred by students (watch television or read a book) (VV10). Based on the significant correlation between "visual-verbal" learning styles and the proposed Design no. 6 (-0.267;
$-0.286 ;-2.63, P<0.01)$ in Table 18, we have the following.

(1) There are 46 out of 100 students who identified Design no. 6 as "intuitive." Most of them are the students who identified themselves as the persons who prefer to watch the television for entertainment (40 students).

(2) There are 59 out of 100 students who identified Design no. 6 as "ergonomic." Most of them are the students who identified themselves as the persons who prefer to watch the television for entertainment (50 students).

(3) While towards the Kansei word "lame versus cool," of the "visual-verbal" learning styles of what the students think about the past (yesterday), they are mostly likely to get "a picture" rather words, that is, 48 students.

(iii) By using the approach that manipulates the answer data of semantic differential ranged within values of 1 to 7 of a pairwise question between the Kansei words into "low", "moderate or neutral," and "high" as described in Table 13, the correlation of the 8 designs proposed that were articulated through Kansei words against the learning style is shown in Table 19. The most numbers that have correlation to the "sensing Intuitive" learning style are related to the way the students like writers when telling the story in the books (SI7), that is, 8 values $(-0.225 ;-0.265$; $-0.242 ;-0.243 ;-0.207 ;-0.246$; and -0.213$)$. Based on what these students like if they are reading the book for enjoyment (SI7), there are more numbers of significant correlation with Design no. 4 related to Kansei words of "fragile versus durable" $(-0.225)$, 
TABLE 14: The correlation between cognitive alert style and Kansei words based on the 8 designs proposed.

\begin{tabular}{|c|c|c|c|c|c|c|c|c|c|}
\hline & Q1 & Q2 & Q3 & Q4 & Q5 & Q6 & Q7 & Q8 & Q9 \\
\hline \multicolumn{10}{|l|}{ Fragile versus Durable-1 } \\
\hline \multicolumn{10}{|l|}{ Fragile versus Durable-2 } \\
\hline \multicolumn{10}{|l|}{ Fragile versus Durable-3 } \\
\hline \multicolumn{10}{|l|}{ Fragile versus Durable- 4} \\
\hline \multicolumn{10}{|l|}{ Fragile versus Durable-5 } \\
\hline Fragile versus Durable-6 & & & $-0.199^{*}$ & & & & & & \\
\hline Fragile versus Durable-7 & & & & & & & & $-0.218^{*}$ & \\
\hline \multicolumn{10}{|l|}{ Fragile versus Durable- 8} \\
\hline \multicolumn{10}{|l|}{ Unattractive versus Attractive- 1} \\
\hline \multicolumn{10}{|l|}{ Unattractive versus Attractive- 2} \\
\hline \multicolumn{10}{|l|}{ Unattractive versus Attractive-3 } \\
\hline \multicolumn{10}{|l|}{ Unattractive versus Attractive- 4} \\
\hline Unattractive versus Attractive- 5 & & & & & & & $-0.209^{*}$ & & \\
\hline Unattractive versus Attractive- 6 & & & & & & & & $-0.206^{*}$ & \\
\hline \multicolumn{10}{|l|}{ Unattractive versus Attractive-7 } \\
\hline Unattractive versus Attractive- 8 & & & & & & & & & \\
\hline
\end{tabular}

Old Fashion versus Modern-1

Old Fashion versus Modern-2

Old Fashion versus Modern-3

Old Fashion versus Modern-4

Old Fashion versus Modern-5

Old Fashion versus Modern-6

Old Fashion versus Modern-7

Old Fashion versus Modern-8

\begin{tabular}{lll}
\hline Lame versus Cool-1 & & \\
Lame versus Cool-2 & & $-0.199^{*}$ \\
Lame versus Cool-3 & $-0.217^{*}$ & $-0.259^{* *}$ \\
Lame versus Cool-4 & $-0.220^{*}$ & $-0.203^{*}$ \\
Lame versus Cool-5 & & \\
Lame versus Cool-6 & & $-0.201^{*}$ \\
Lame versus Cool-7 & & \\
Lame versus Cool-8 & & \\
\hline Unintuitive versus Intuitive-1 & &
\end{tabular}

Unintuitive versus Intuitive-2

Unintuitive versus Intuitive-3

Unintuitive versus Intuitive-4

Unintuitive versus Intuitive-5

Unintuitive versus Intuitive- 6

Unintuitive versus Intuitive-7

Unintuitive versus Intuitive- 8

Inconvenient versus Ergonomic-1

Inconvenient versus Ergonomic-2

Inconvenient versus Ergonomic-3

Inconvenient versus Ergonomic-4

Inconvenient versus Ergonomic-5

Inconvenient versus Ergonomic-6

Inconvenient versus Ergonomic-7

Inconvenient versus Ergonomic-8

${ }^{*}$ Correlation is significant at the 0.05 level (2 tailed).

${ }^{* *}$ Correlation is significant at the 0.01 level ( 2 tailed). 
TABLE 15: The interpretation of Design no. 5 versus the way of students doing the Job (Q7) and the outcome of students doing the arranging (Q6).

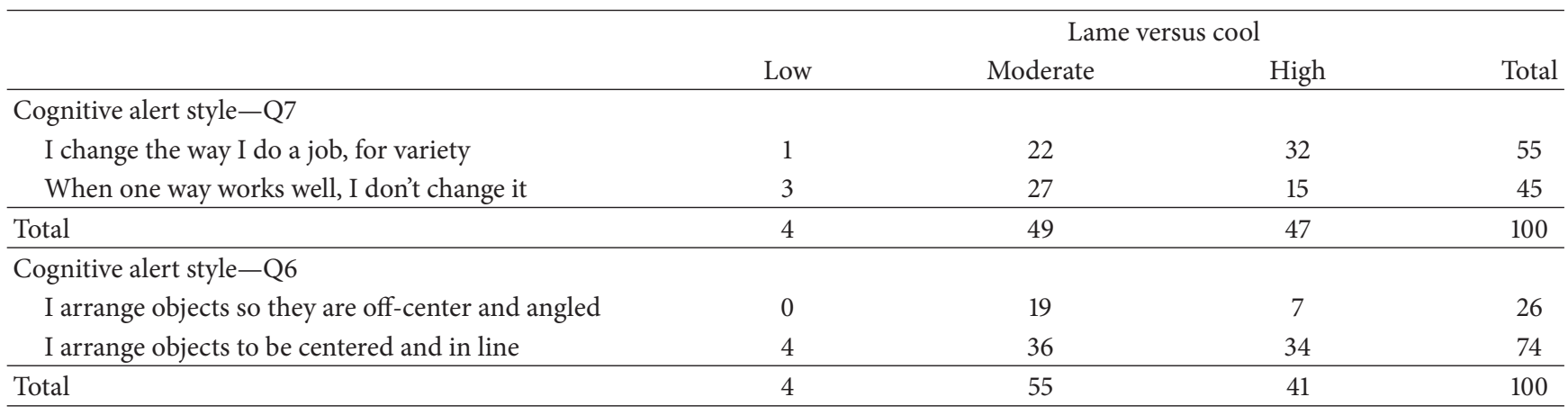

"unattractive versus attractive" (-0.225), "old fashion versus modern" (-0.243), and "lame versus cool" $(-0.213)$.

(iv) Table 20 shows the following.

(1) There are 66 out of 100 students who identified Design no. 4 as "fragile." Most of them are the students who identified themselves as the persons who prefer the way of writers telling the story in the books with saying things in creative interesting way (SI7), that is, 53 students.

(2) There are 53 out of 100 students who identified Design no. 4 as "unattractive." Most of them are the students who identified themselves as the persons who prefer the way of writers telling the story in the books with saying things in creative interesting way (SI7), that is, 42 students.

(3) There are 55 out of 100 students who identified Design no. 4 as "old fashion." Most of them are the students who identified themselves as the persons prefer the way of writers telling the story in the books with saying things in creative interesting way (SI7), that is, 43 students.

(4) There are 58 out of 100 students who identified Design no. 4 as "lame." Most of them are the students who identified themselves as the persons prefer the way of writers telling the story in the books with saying things in creative interesting way (SI7), that is, 44 students. For the correlation between learning styles versus Kansei words based on the 8 designs proposed see Table 19.

(v) The most numbers having significant correlation between "visual-verbal" and the 8 designs proposed is about how the teacher carried out the teaching way that students like (VV4) and what kind of the entertainment preferred by students (VV10), that is, 8 and 6 , respectively. These learnings style are mostly having significant correlation number to Design no. 5 $(-0.263 ;-0.231 ;-0.262$; and -0.202$)$ and Design no. $6(-0.209 ;-0.219 ;-0.240$; and -0.288$)$, respectively. (vi) The learning style of "visual-verbal" type towards Design no. 5 articulated using Kansei words (Table 21) is as follows.

(1) There are 92 out of 100 students who identified Design no. 5 as "durable." Most of them are the students who like the teacher to put a lot diagrams on the board (VV4), that is, 63 students.

(2) There are 79 out of 100 students who identified Design no. 5 as "unattractive." Most of them are the students who like the teacher to put a lot diagrams on the board (VV4), that is, 56 students.

(3) There are 75 out of 100 students who identified Design no. 5 as "old fashion." Most of them are the students who like the teacher to put a lot diagrams on the board (VV4), that is, 55 students.

(4) There are 79 out of 100 students who identified Design no. 5 as "lame." Most of them are the students who like the teacher to put a lot diagrams on the board (VV4), that is, 56 students.

(vii) The learning style of "visual-verbal" type towards the proposed Design no. 6 articulated using Kansei words as shown in Table 22 is follows.

(1) There are 48 out of 100 students who identified Design no. 6 as "durable." Most of them are the students who identified themselves as the persons who prefer to watch the television for entertainment (VV10), that is, 43 students.

(2) There are 51 out of 100 students who identified Design no. 6 as "attractive." Most of them are the students who identified themselves as the persons who prefer to watch the television for entertainment (VV10), that is, 43 students.

(3) There are 51 out of 100 students who identified Design no. 6 as "cool." Most of them are the students who identified themselves as the persons who prefer to watch the television for entertainment (VV10), that is, 43 students. 
TABLE 16: The correlation between learning style and Kansei words based on the 8 designs proposed.

\begin{tabular}{|c|c|c|c|c|c|c|c|c|c|c|c|}
\hline Kansei word & SI-1 & SI-2 & SI-3 & SI-4 & SI-5 & SI-6 & SI-7 & SI-8 & SI-9 & SI-10 & SI-11 \\
\hline \multicolumn{12}{|l|}{ Design-1 } \\
\hline \multicolumn{12}{|l|}{ 1-Fragile-Durable } \\
\hline 1-Unattractive-Attractive & & & & & & & $-0.286^{* *}$ & & & & \\
\hline \multicolumn{12}{|l|}{ 1-Old Fashion-Modern } \\
\hline 1-Lame-Cool & & & & & & & $-0.256^{*}$ & & & & \\
\hline \multicolumn{12}{|l|}{ 1-Unintuitive-Intuitive } \\
\hline \multicolumn{12}{|l|}{ 1-Inconvenient-Ergonomic } \\
\hline \multicolumn{12}{|l|}{ Design-2 } \\
\hline 2-Fragile-Durable & & & & & & & $-0.211^{*}$ & & & & \\
\hline 2-Unattractive-Attractive & & & & & & & $-0.288^{* *}$ & $-0.233^{*}$ & & & \\
\hline 2-Old Fashion-Modern & & & & & & & $-0.211^{*}$ & & & & \\
\hline 2-Lame-Cool & & & & & & & $-0.231^{*}$ & & & & \\
\hline 2-Unintuitive-Intuitive & $0.247^{*}$ & & & & & & & & & & \\
\hline 2-Inconvenient-Ergonomic & & & $-0.207^{*}$ & & & & & & & & \\
\hline \multicolumn{12}{|l|}{ Design-3 } \\
\hline \multicolumn{12}{|l|}{ 3-Fragile-Durable } \\
\hline \multicolumn{12}{|l|}{ 3-Unattractive-Attractive } \\
\hline \multicolumn{12}{|l|}{ 3-Old Fashion-Modern } \\
\hline \multicolumn{12}{|l|}{ 3-Lame-Cool } \\
\hline \multicolumn{12}{|l|}{ 3-Unintuitive-Intuitive } \\
\hline 3-Inconvenient-Ergonomic & & & & & & & & & $-0.202^{* *}$ & & \\
\hline \multicolumn{12}{|l|}{ Design-4 } \\
\hline 4-Fragile-Durable & & & & & & & $-0.206^{*}$ & & & & \\
\hline 4-Unattractive-Attractive & & & & & & & $-0.230^{*}$ & & & & \\
\hline 4-Old Fashion-Modern & & & & & & & $-0.202^{*}$ & & & & \\
\hline \multicolumn{12}{|l|}{ 4-Lame-Cool } \\
\hline \multicolumn{12}{|l|}{ 4-Unintuitive-Intuitive } \\
\hline 4-Inconvenient-Ergonomic & & & & & & & & & $-0.205^{*}$ & & \\
\hline \multicolumn{12}{|l|}{ Design-5 } \\
\hline 5-Fragile-Durable & & & & $0.320^{* *}$ & & & & & & & \\
\hline \multicolumn{12}{|l|}{ 5-Unattractive-Attractive } \\
\hline \multicolumn{12}{|l|}{ 5-Old Fashion-Modern } \\
\hline 5-Lame-Cool & & & & & & & & & & & \\
\hline 5-Unintuitive-Intuitive & & & & & & & & & & & \\
\hline 5-Inconvenient-Ergonomic & $0.207^{*}$ & & & $0.225^{*}$ & & & & & & & \\
\hline Design-6 & & & & & & & & & & & \\
\hline 6-Fragile-Durable & & & $0.236^{*}$ & & & & & & & & \\
\hline 6-Unattractive-Attractive & & & $0.207^{*}$ & & & & & & & & \\
\hline 6-Old Fashion-Modern & & & & & & & & & & & \\
\hline 6-Lame-Cool & & & $0.217^{*}$ & & & & & & & & \\
\hline 6-Unintuitive-Intuitive & & & & & & & & & & $-0.203^{*}$ & \\
\hline 6-Inconvenient-Ergonomic & & & & & & & & & & $-0.207^{*}$ & \\
\hline Design-7 & & & & & & & & & & & \\
\hline 7-Fragile -Durable & & & & & & & & & & & \\
\hline 7-Unattractive-Attractive & & & & & & & & & & & \\
\hline 7-Old Fashion-Modern & & & & & & & & & & & \\
\hline 7-Lame-Cool & & & & $0.200^{*}$ & & & & & & & \\
\hline 7-Unintuitive-Intuitive & & $-0.225^{*}$ & & & & & & & & & \\
\hline 7-Inconvenient-Ergonomic & & & & & & & & & & & \\
\hline
\end{tabular}


TABle 16: Continued.

\begin{tabular}{|c|c|c|c|c|c|c|c|c|c|c|c|}
\hline Kansei word & SI-1 & SI-2 & SI-3 & SI-4 & SI-5 & SI-6 & SI-7 & SI-8 & SI-9 & SI-10 & SI-11 \\
\hline \multicolumn{12}{|l|}{ Design-8 } \\
\hline \multicolumn{12}{|l|}{ 8-Fragile-Durable } \\
\hline \multicolumn{12}{|l|}{ 8-Unattractive-Attractive } \\
\hline \multicolumn{12}{|l|}{ 8-Old Fashion-Modern } \\
\hline 8-Lame-Cool & & & & & & & & $-0.211^{*}$ & & & \\
\hline \multicolumn{12}{|l|}{ 8-Unintuitive-Intuitive } \\
\hline 8-Inconvenient-Ergonomic & & & & & & & & $-0.202^{*}$ & & & \\
\hline Kansei word & VV1 & VV2 & VV3 & VV4 & VV5 & VV6 & VV7 & VV8 & VV9 & VV10 & VV11 \\
\hline \multicolumn{12}{|l|}{ Design-1 } \\
\hline \multicolumn{12}{|l|}{ 1-Fragile-Durable } \\
\hline \multicolumn{12}{|l|}{ 1-Unattractive-Attractive } \\
\hline 1-Old Fashion-Modern & & & & & & & & $0.247^{*}$ & & & \\
\hline 1-Lame-Cool & & & & & & & & $0.227^{*}$ & & & \\
\hline 1-Unintuitive-Intuitive & & & & & & & & $0.255^{*}$ & & & \\
\hline 1-Inconvenient-Ergonomic & & & & $-0.247^{*}$ & & & & & & & \\
\hline \multicolumn{12}{|l|}{ Design-2 } \\
\hline \multicolumn{12}{|l|}{ 2-Fragile-Durable } \\
\hline \multicolumn{12}{|l|}{ 2-Unattractive-Attractive } \\
\hline 2-Old Fashion-Modern & & & $0.210^{*}$ & & & & $0.199^{*}$ & & & & \\
\hline \multicolumn{12}{|l|}{ 2-Lame-Cool } \\
\hline 2-Unintuitive-Intuitive & & & & & & & $0.215^{*}$ & & & & \\
\hline \multicolumn{12}{|l|}{ 2-Inconvenient-Ergonomic } \\
\hline \multicolumn{12}{|l|}{ Design-3 } \\
\hline 3-Fragile-Durable & & & & & & & & & $-0.280^{*}$ & & \\
\hline 3-Unattractive-Attractive & & & & & & & & & $-0.225^{*}$ & & \\
\hline \multicolumn{12}{|l|}{ 3-Old Fashion-Modern } \\
\hline \multicolumn{12}{|l|}{ 3-Lame-Cool } \\
\hline \multicolumn{12}{|l|}{ 3-Unintuitive-Intuitive } \\
\hline 3-Inconvenient-Ergonomic & & & & & & & & & $-0.200^{*}$ & & \\
\hline \multicolumn{12}{|l|}{ Design-4 } \\
\hline 4-Fragile-Durable & & & & & & & & & $-0.267^{* *}$ & & \\
\hline 4-Unattractive-Attractive & & & & & & & & & & & \\
\hline 4-Old Fashion-Modern & & & & & & & & & & & \\
\hline 4-Lame-Cool & & & & & & & & & & & \\
\hline 4-Unintuitive-Intuitive & & & & & & & & & & & \\
\hline 4-Inconvenient-Ergonomic & & & & & & & & & & & \\
\hline Design-5 & & & & & & & & & & & \\
\hline 5-Fragile-Durable & & & $-0.203^{*}$ & & & & & & & & \\
\hline 5-Unattractive-Attractive & & & & $-0.198^{*}$ & & & & & & & \\
\hline 5-Old Fashion-Modern & & & & & & & & & & & \\
\hline 5-Lame-Cool & & & & & & & & & & & \\
\hline 5-Unintuitive-Intuitive & & & & $-0.217^{*}$ & & & & & & & \\
\hline 5-Inconvenient-Ergonomic & & & & $-0.205^{*}$ & & & & & & & \\
\hline Design-6 & & & & & & & & & & & \\
\hline 6-Fragile-Durable & & & & & & & & & & $-0.255^{*}$ & \\
\hline 6-Unattractive-Attractive & & & & & & & & & & $-0.299^{*}$ & \\
\hline 6-Old Fashion-Modern & & & & & & & & & & & \\
\hline 6-Lame-Cool & $-0.263^{* *}$ & & & & & & & & & $-0.230^{*}$ & \\
\hline 6-Unintuitive-Intuitive & $-0.200^{*}$ & & & & & $-0.200^{*}$ & & & & $-0.267^{* *}$ & \\
\hline 6-Inconvenient-Ergonomic & $-0.202^{*}$ & & & & & & & & & $-0.286^{* *}$ & \\
\hline
\end{tabular}


TABLE 16: Continued.

\begin{tabular}{|c|c|c|c|c|c|c|c|c|c|c|c|}
\hline Kansei word & VV1 & VV2 & VV3 & VV4 & VV5 & VV6 & VV7 & VV8 & VV9 & VV10 & VV11 \\
\hline \multicolumn{12}{|l|}{ Design-7 } \\
\hline 7-Fragile -Durable & $-0.230^{*}$ & & & & & & $-0.200^{*}$ & & & & \\
\hline 7-Unattractive-Attractive & & & $-0.214^{*}$ & & & & & & & & \\
\hline \multicolumn{12}{|l|}{ 7-Old Fashion-Modern } \\
\hline 7-Lame-Cool & & & & & & & $-0.200^{*}$ & & & & \\
\hline 7-Unintuitive-Intuitive & & & & & & & & & & $-0.204^{*}$ & \\
\hline \multicolumn{12}{|l|}{ 7-Inconvenient-Ergonomic } \\
\hline Design-8 & & & & & & & & $-0.214^{*}$ & & & \\
\hline \multicolumn{12}{|l|}{ 8-Fragile-Durable } \\
\hline \multicolumn{12}{|l|}{ 8-Unattractive-Attractive } \\
\hline \multicolumn{12}{|l|}{ 8-Old Fashion-Modern } \\
\hline \multicolumn{12}{|l|}{ 8-Lame-Cool } \\
\hline \multicolumn{12}{|l|}{ 8-Unintuitive-Intuitive } \\
\hline 8-Inconvenient-Ergonomic & & & & $0.209^{*}$ & & & & & & & \\
\hline
\end{tabular}

${ }^{*}$ Correlation is significant at the 0.05 level ( 2 tailed).

${ }^{* *}$ Correlation is significant at the 0.01 level ( 2 tailed).

TABLE 17: The interpretation of Design no. 2 versus the students preferences in enjoyment of reading the book (SI7).

\begin{tabular}{lccccccc}
\hline $\begin{array}{l}\text { Learning style of } \\
\text { Sensing-Intuitive (SI7) }\end{array}$ & $\begin{array}{c}\text { Very } \\
\text { unattractive }\end{array}$ & Attractive & $\begin{array}{c}\text { Less } \\
\text { unattractive }\end{array}$ & $\begin{array}{c}\text { Not } \\
\text { attractive }\end{array}$ & $\begin{array}{c}\text { Less } \\
\text { attractive }\end{array}$ & Attractive & $\begin{array}{c}\text { Very } \\
\text { attractive }\end{array}$ \\
\hline $\begin{array}{l}\text { Clearly say what they mean } \\
\begin{array}{l}\text { Say things in creative, } \\
\text { interesting way }\end{array}\end{array}$ & 3 & 5 & 6 & 6 & 6 & 1 & 1 \\
\hline Total & 19 & 24 & 15 & 15 & 3 & 2 & 2 \\
\hline
\end{tabular}

(4) There are 46 out of 100 students who identified Design no. 6 as "intuitive." Most of them are the students who identified themselves as the persons who prefer to watch the television for entertainment (VV10), that is, 40 students.

(5) There are 59 out of 100 students who identified Design no. 6 as "ergonomic." Most of them are the students who identified themselves as the persons who prefer to watch the television for entertainment (VV10), that is, 40 students.

\subsection{The Correlation between Cognitive Alert Style and}

\section{Learning Style towards the Design Proposed Preferences}

(a) Based on the preferences determined by the respondents (students who are spectacles users) towards the 8 designs proposed related to the cognitive alert style, it shows that the proposed Designs nos. 1 and 2 are having significant correlation with what the students think about themselves (Table 23). However, the value of this significant correlation is low. Most of them who feel that the other think about his or her as the person who organize things well (Q5) is 30 out of 100 , while towards how to fulfill the priority of work (the important things first and other things later) (Q4) is
61 out 100 identifying the proposed Design no. 2 as "dislike" or "not preference."

(b) Based on the preferences determined by the respondents (students who are spectacles users) towards the 8 designs proposed related to learning style of "sensing-intuitive" learner type, we have the following.

(1) The preferences of the proposed Designs nos. 3 and 8 were having significant correlation with "sensing" and "intuitive" types of learning styles (Table 24).

(2) The proposed Designs nos. 2, 3, 4, and 5 are having significant correlation with what the students feel and think about how to find the easier for them (to learn the facts or concept) (SI3), the writing style of book that they like (SI7), and what they feel as a praising when calling someone (SI9). Here, 71 out of 100 students who prefer to like the writers saying things in creative and interesting way in the books (SI7) determined the proposed Design no. 2 as "dislike" or "not preference" (Table 12), while the students who prefer to learn concept than facts as it is easier (SI3) (52 of out 100 students), they consider the Design proposed no. 5 is what their preference or "like" (Table 25(a)). 
TABLE 18: The Interpretation of Design no. 6 versus the the students preferences related to entertainment (VV10) and the memorization (VV1). (Based on kansei words Unintuitive-Intuitive, Inconvenient-Ergonomic, and Lame-Cool].

\begin{tabular}{|c|c|c|c|c|c|c|c|c|}
\hline \multirow{2}{*}{$\begin{array}{l}\text { Learning Style of } \\
\text { Visual-Verbal (VV10) }\end{array}$} & \multicolumn{7}{|c|}{ Unintuitive versus Intuitive- 6} & \multirow[b]{2}{*}{ Total } \\
\hline & $\begin{array}{c}\text { Very } \\
\text { unintuitive }\end{array}$ & Unintuitive & $\begin{array}{c}\text { Less } \\
\text { unintuitive }\end{array}$ & $\begin{array}{c}\text { Not } \\
\text { intuitive }\end{array}$ & $\begin{array}{c}\text { Less } \\
\text { intuitive }\end{array}$ & Intuitive & $\begin{array}{l}\text { Very } \\
\text { intuitive }\end{array}$ & \\
\hline $\begin{array}{l}\text { For entertainment, I would } \\
\text { rather watch television }\end{array}$ & 1 & 4 & 8 & 24 & 18 & 15 & 7 & 77 \\
\hline $\begin{array}{l}\text { For entertainment, I would } \\
\text { rather read a book }\end{array}$ & 1 & 3 & 3 & 10 & 5 & 1 & 0 & 23 \\
\hline Total & 2 & 7 & 11 & 34 & 23 & 16 & 7 & 100 \\
\hline \multirow{2}{*}{$\begin{array}{l}\text { Learning style of } \\
\text { Visual-Verbal (VV10) }\end{array}$} & \multicolumn{7}{|c|}{ Inconvenient versus Ergonomic-6 } & \multirow[b]{2}{*}{ Total } \\
\hline & $\begin{array}{c}\text { Very } \\
\text { inconvenient }\end{array}$ & Inconvenient & $\begin{array}{c}\text { Less } \\
\text { convenient }\end{array}$ & $\begin{array}{l}\text { Not } \\
\text { ergonomic }\end{array}$ & $\begin{array}{c}\text { Less } \\
\text { ergonomic }\end{array}$ & Ergonomic & $\begin{array}{c}\text { Very } \\
\text { ergonomic }\end{array}$ & \\
\hline $\begin{array}{l}\text { For entertainment, I would } \\
\text { rather watch television }\end{array}$ & 2 & 3 & 9 & 13 & 22 & 17 & 11 & 77 \\
\hline $\begin{array}{l}\text { For entertainment, I would } \\
\text { rather read a book }\end{array}$ & 1 & 3 & 4 & 6 & 8 & 1 & 0 & 23 \\
\hline Total & 3 & 6 & 13 & 9 & 30 & 18 & 11 & 100 \\
\hline \multirow{2}{*}{$\begin{array}{l}\text { Learning style of } \\
\text { Visual-Verbal (VV1) }\end{array}$} & \multicolumn{7}{|c|}{ Lame versus Cool-6 } & \multirow{2}{*}{ Total } \\
\hline & Very lame & Lame & Less lame & Not cool & Less cool & Cool & Very cool & \\
\hline \multicolumn{9}{|l|}{$\begin{array}{l}\text { When I think about } \\
\text { yesterday I am most likely } \\
\text { to get: }\end{array}$} \\
\hline a picture & 4 & 6 & 7 & 20 & 21 & 20 & 7 & 77 \\
\hline words & 1 & 2 & 4 & 5 & 3 & 0 & 0 & 23 \\
\hline Total & 5 & 8 & 11 & 25 & 24 & 20 & 7 & 100 \\
\hline
\end{tabular}

(c) Based on the preferences determined by the respondents (students who are spectacles users) towards the 8 designs proposed related to the learning style of "verbal-visual" learner type, it shows that the proposed Design no. 6 having more numbers of significant correlation with what the students prefer to getting the new information (VV2), what they are likely to do in a book with lots of pictures and charts (VV3), and the entertainment type (VV10). Table 25(b) shows what follows.

(1) There are 73 out of 100 students who prefer Design no. 5. Most of them are the students who identified themselves as the persons who prefer to look over pictures and chart carefully rather than written text (VV3) (67 students).

(2) There are 52 out of 100 students who prefer Design no. 6. Most of them are the students that identified themselves as the persons who prefer to look over pictures and chart carefully rather than written text (VV3) (45 students).

(3) There are 53 out of 100 students who prefer the Design no. 6. Most of them are the students that identified themselves as the persons that when thinking about what he/she did yesterday are most likely to get a picture (VV1) (46 students).

(4) There are 53 out of 100 students who prefer Design no. 6. Most of them are the students that identified themselves as the person who more likely to remember someone as what they looked like when meeting people at a party (VV9) (42 students).

\section{Conclusion and Recommendation}

The results show that this study provides an overview of learning styles among manufacturing engineering students, especially the students who are using spectacles for improving their visual abilities. They are as follows.

(i) Based on the student learning style, there are significant correlations found between "sensing-intuitive" and "visual-verbal" learning styles (Table 7).

(ii) Mostly of the students were having the learning styles dominated with "intuitive" and "visual" learner types (53 and 87 students, resp.). However, the significant correlation to the cognitive alert styles only occurred on "sensing" and "intuitive" learner types. It is also noted that the significant correlation between the "intuitive" types of learning styles to the cognitive alert styles (Q8) is negative values.

(iii) In order to determine the most weighted value for decision making (articulated with "like versus dislike"), this study found that the students who are using spectacles (representing the visualizer characteristics) determined the proposed Design no. 5 as a highest 
TABLE 19: The correlation between learning style and Kansei words based on the 8 designs proposed.

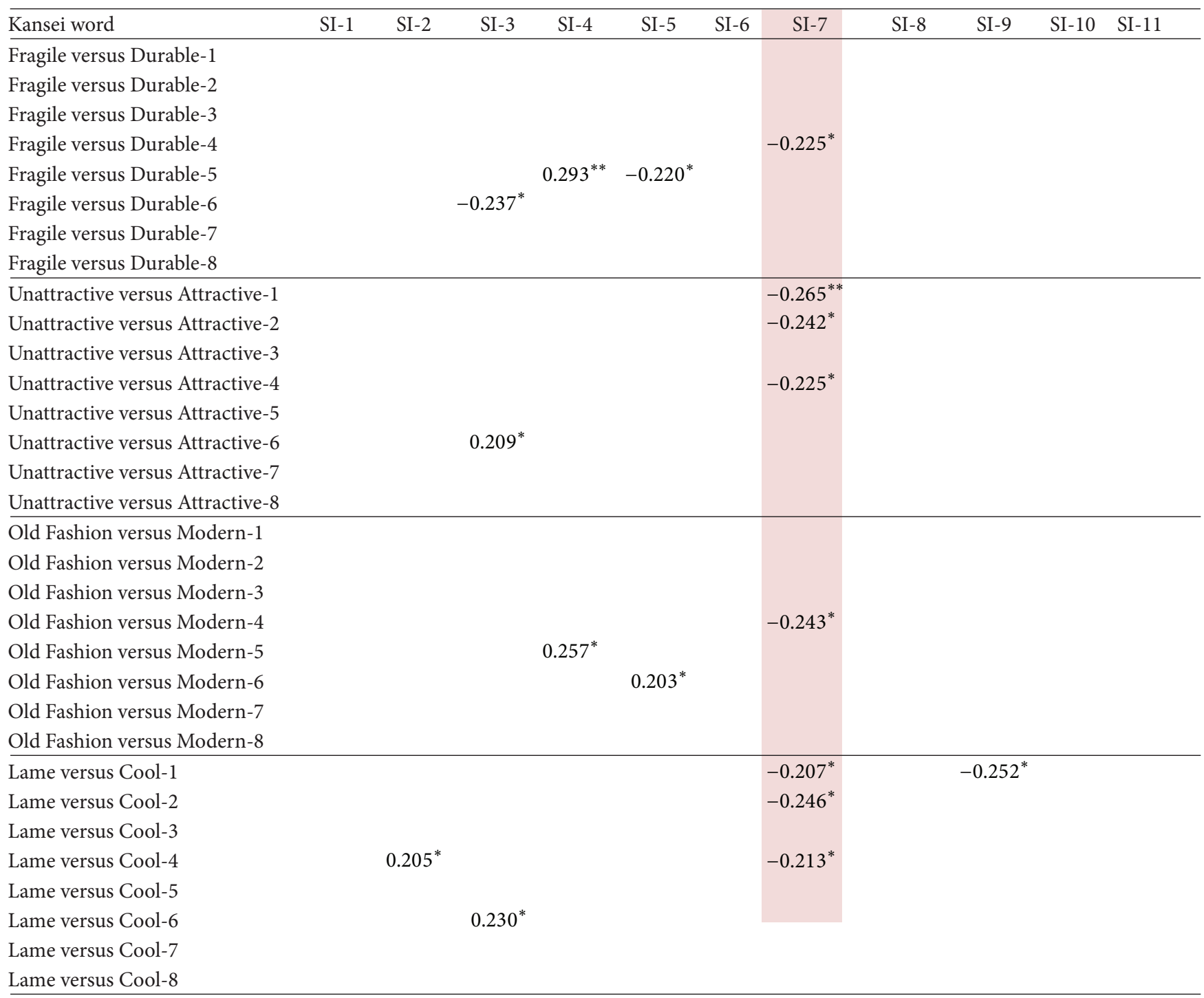

Unintuitive versus Intuitive-1

Unintuitive versus Intuitive-2

$0.234^{*}$

Unintuitive versus Intuitive-3

Unintuitive versus Intuitive- 4

Unintuitive versus Intuitive-5

$\begin{array}{cc}0.217^{*} & -0.266^{* *} \\ & -0.248^{*} \\ -0.231^{*} & -0.201^{*}\end{array}$

Unintuitive versus Intuitive-6

Unintuitive versus Intuitive-7

Unintuitive versus Intuitive- 8

Inconvenient versus Ergonomic-1

Inconvenient versus Ergonomic-2

Inconvenient versus Ergonomic-3

Inconvenient versus Ergonomic-4

Inconvenient versus Ergonomic-5

Inconvenient versus Ergonomic-6 
TABle 19: Continued.

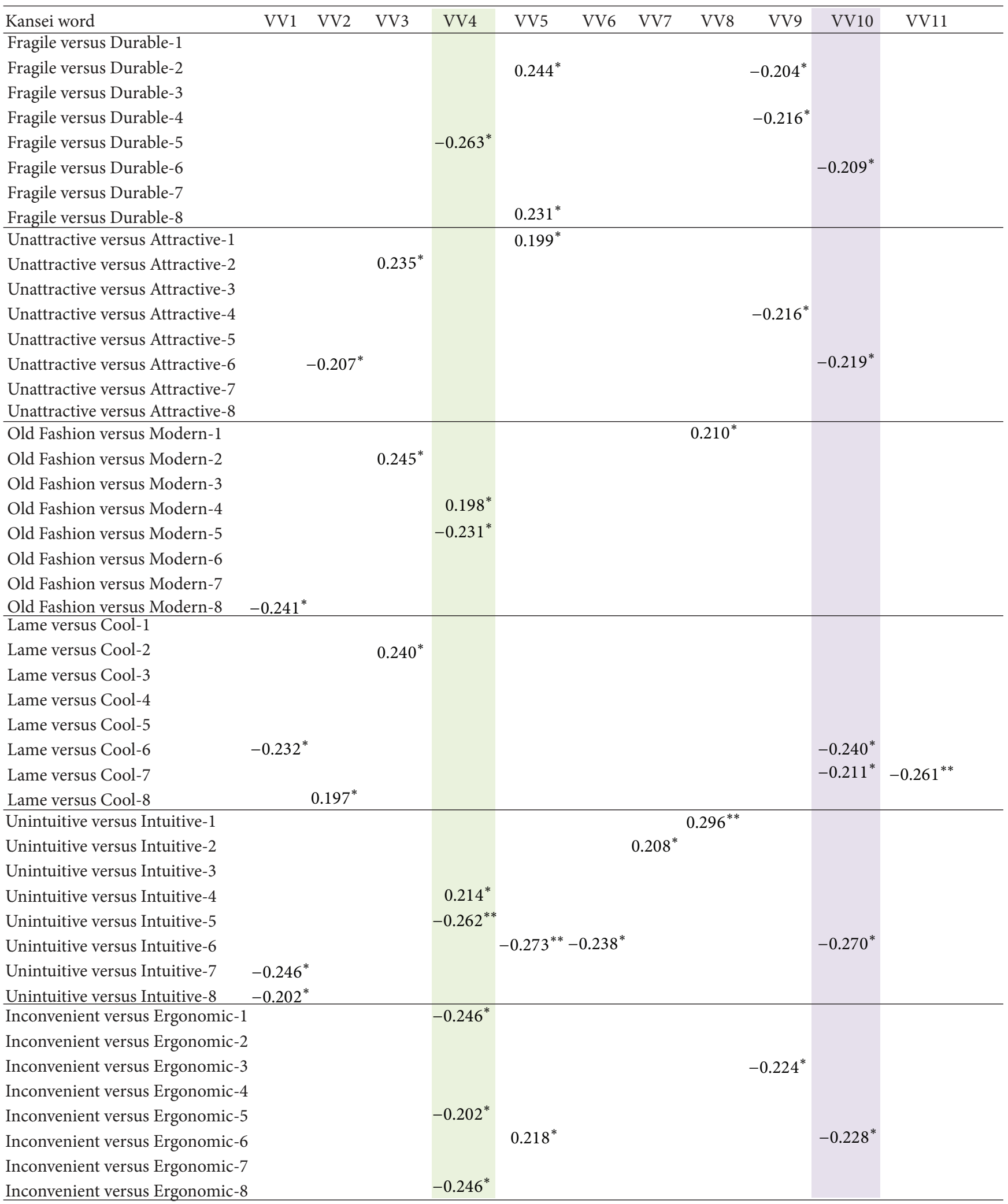

${ }^{*}$ Correlation is significant at the 0.05 level (2 tailed).

${ }^{* *}$ Correlation is significant at the 0.01 level ( 2 tailed). 
TABLE 20: The Interpretation of Design no. 4 versus the students preferences in enjoyment of reading the book (SI7) (Based on Kansei words of fragile—durable, unattractive—attractive, old fashion—-modern, lame-cool].

\begin{tabular}{|c|c|c|c|c|c|c|c|c|}
\hline \multirow{2}{*}{$\begin{array}{l}\text { Learning style of } \\
\text { Sensing-Intuitive (SI7) }\end{array}$} & \multirow[b]{2}{*}{ Very fragile } & \multicolumn{6}{|c|}{ 4-Fragile versus Durable } & \multirow[b]{2}{*}{ Tota } \\
\hline & & Fragile & Less fragile & Not durable & Less durable & Durable & $\begin{array}{c}\text { Very } \\
\text { durable }\end{array}$ & \\
\hline Clearly say what they mean & 7 & 2 & 4 & 9 & 4 & 1 & 1 & 28 \\
\hline $\begin{array}{l}\text { Say things in creative } \\
\text { interesting ways }\end{array}$ & 23 & 16 & 14 & 9 & 9 & 0 & 1 & 72 \\
\hline Total & 30 & 18 & 18 & 18 & 13 & 1 & 2 & 100 \\
\hline \multirow{2}{*}{$\begin{array}{l}\text { Learning style of } \\
\text { Sensing-Intuitive (SI7) }\end{array}$} & \multicolumn{7}{|c|}{ Unattractive versus Attractive- 4} & \multirow[b]{2}{*}{ Total } \\
\hline & $\begin{array}{c}\text { Very } \\
\text { unattractive }\end{array}$ & Attractive & $\begin{array}{c}\text { Less } \\
\text { unattractive }\end{array}$ & $\begin{array}{c}\text { Not } \\
\text { attractive }\end{array}$ & $\begin{array}{c}\text { Less } \\
\text { attractive }\end{array}$ & Attractive & $\begin{array}{c}\text { Very } \\
\text { attractive }\end{array}$ & \\
\hline Clearly say what they mean & 4 & 1 & 6 & 8 & 3 & 3 & 3 & 28 \\
\hline $\begin{array}{l}\text { Say things in creative } \\
\text { interesting ways }\end{array}$ & 15 & 18 & 9 & 14 & 11 & 4 & 1 & 72 \\
\hline Total & 19 & 19 & 15 & 22 & 14 & 7 & 4 & 100 \\
\hline \multirow{2}{*}{$\begin{array}{l}\text { Learning style of } \\
\text { Sensing-Intuitive (SI7) }\end{array}$} & \multicolumn{7}{|c|}{ Old Fashion versus Modern-4 } & \multirow[b]{2}{*}{ Total } \\
\hline & Very old & Old & Less old & Not modern & $\begin{array}{c}\text { Less } \\
\text { modern }\end{array}$ & Modern & $\begin{array}{c}\text { Very } \\
\text { attractive }\end{array}$ & \\
\hline Clearly say what they mean & 3 & 2 & 7 & 9 & 3 & 1 & 3 & 28 \\
\hline $\begin{array}{l}\text { Say things in creative, } \\
\text { interesting way }\end{array}$ & 17 & 11 & 15 & 13 & 13 & 2 & 1 & 72 \\
\hline Total & 20 & 13 & 22 & 22 & 16 & 3 & 4 & 100 \\
\hline \multirow{2}{*}{$\begin{array}{l}\text { Learning style of } \\
\text { Sensing-Intuitive (SI7) }\end{array}$} & \multicolumn{7}{|c|}{ Lame versus Cool- 4} & \multirow[b]{2}{*}{ Total } \\
\hline & Very lame & Lame & Less lame & Not cool & Less cool & Cool & Very cool & \\
\hline Clearly say what they mean & 3 & 3 & 8 & 7 & 3 & 3 & 1 & 28 \\
\hline $\begin{array}{l}\text { Say things in creative, } \\
\text { interesting way }\end{array}$ & 16 & 12 & 16 & 13 & 12 & 2 & 1 & 72 \\
\hline Total & 19 & 15 & 24 & 20 & 15 & 5 & 2 & 100 \\
\hline
\end{tabular}

preference of the spectacle design (5.52), while for Kansei words that represen verbalizer characteristics, the highest is on "inconvenient versus ergonomic" (4.65 and 4.87 for values of 5 and 6, resp.) (Table 3). This is shown also in Figure 4 where the proposed Design no. 5 and Kansei word of "inconvenient versus ergonomic" are having the highest scores.

(iv) Based on the 8 frame designs proposed (Figure 2), the thicker/bold of frame is interpreted as "durable" and "ergonomics," while the rimless design is interpreted as "fragile" (Figure 6).

Based on this finding, we can conclude as follows.

(1) Cognitive Alert Style and Learning Style.

(i) The students who proud of the creativity of their work (70 out of 100 students) are almost to consider themselves similar as realistic or innovative persons (SI1) rather than the thoroughness of their work (30 out of 100 students). Here, they are more likely to be considered as realistic persons rather than innovative persons (21 and 9 students, resp.). In addition, the students who are proud of the creativity of their work confessed that they prefer to be considered as creative about how they do their work rather than careful about the details of their work (41 versus 29 students).

(ii) The students who confessed that when they take a "break," they find something different to do, are likely to repeat all the steps and check their work carefully (41 out of 100 students) rather than the students who confessed that when they take a "break," they relax and do nothing, that more preferably to checking their work tiresome and have to force themselves to do it (24 out of 100 students).

(iii) The students who feel that people find his/herself organize things well rather than not (Q5) (that is 70 out of 100 students) are almost similar in considering high praise to call someone (SI9) (that is, 32 and 38 , resp.). However, they are different for those who feel people find he/she unorganized, where they give higher praise to imaginative rather sensible person.

(2) The Spectacles Designs Proposed Using Kansei Words toward Cognitive Alert Styles and Learning Styles.

(i) The Kansei words "old fashion versus modern" and "inconvenient versus ergonomic" (as the articulation of the 8 designs proposed) do not have any correlation towards cognitive alert styles. 
TABLE 21: The Interpretation of Design no. 5 versus the the students preferences related to teaching delivery (VV4) (Based on Kansei words Fragile-Durable, Old Fashion-Modern, Unintuitive-Intuitive, Inconvenient-Ergonomic).

\begin{tabular}{|c|c|c|c|c|c|c|c|c|}
\hline \multirow{2}{*}{$\begin{array}{l}\text { Learning style of } \\
\text { Visual-Verbal (VV4) }\end{array}$} & \multicolumn{7}{|c|}{ Fragile versus Durable- 4} & \multirow[b]{2}{*}{ Total } \\
\hline & Very fragile & Fragile & Less fragile & Not durable & Less durable & Durable & $\begin{array}{c}\text { Very } \\
\text { durable }\end{array}$ & \\
\hline $\begin{array}{l}\text { I like teacher who put a } \\
\text { lot of diagrams on the } \\
\text { board }\end{array}$ & 1 & 0 & & 3 & 24 & 23 & 16 & 67 \\
\hline $\begin{array}{l}\text { I like teacher who spend } \\
\text { a lot of time explaining }\end{array}$ & 1 & 2 & & 1 & 17 & 4 & 8 & 33 \\
\hline Total & 2 & 2 & & 4 & 41 & 27 & 24 & 100 \\
\hline \multirow{2}{*}{$\begin{array}{l}\text { Learning style of } \\
\text { Visual-Verbal (VV4) }\end{array}$} & \multicolumn{7}{|c|}{ Old Fashion versus Modern-5 } & \multirow[b]{2}{*}{ Total } \\
\hline & Very old & Old & Less old & Not modern & $\begin{array}{c}\text { Less } \\
\text { modern }\end{array}$ & Modern & $\begin{array}{c}\text { Very } \\
\text { attractive }\end{array}$ & \\
\hline $\begin{array}{l}\text { I like teacher who put a } \\
\text { lot of diagrams on the } \\
\text { board }\end{array}$ & 1 & 0 & 3 & 8 & 15 & 22 & 19 & 68 \\
\hline $\begin{array}{l}\text { I like teacher who spend } \\
\text { a lot of time explaining }\end{array}$ & 2 & 0 & 2 & 5 & 11 & 6 & 6 & 32 \\
\hline Total & 3 & 0 & 5 & 13 & 26 & 28 & 25 & 100 \\
\hline \multirow{2}{*}{$\begin{array}{l}\text { Learning style of } \\
\text { Visual-Verbal (VV4) }\end{array}$} & \multicolumn{7}{|c|}{ Unintuitive versus Intuitive-5 } & \multirow[b]{2}{*}{ Total } \\
\hline & $\begin{array}{c}\text { Very } \\
\text { unintuitive }\end{array}$ & Unintuitive & $\begin{array}{c}\text { Less } \\
\text { unintuitive }\end{array}$ & $\begin{array}{c}\text { Not } \\
\text { intuitive }\end{array}$ & $\begin{array}{c}\text { Less } \\
\text { intuitive }\end{array}$ & Intuitive & $\begin{array}{c}\text { Very } \\
\text { intuitive }\end{array}$ & \\
\hline $\begin{array}{l}\text { I like teacher who put a } \\
\text { lot of diagrams on the } \\
\text { board }\end{array}$ & 1 & 0 & 1 & 11 & 22 & 22 & 11 & 68 \\
\hline $\begin{array}{l}\text { I like teacher who spend } \\
\text { a lot of time explaining }\end{array}$ & 1 & 2 & 0 & 9 & 12 & 3 & 5 & 32 \\
\hline Total & 2 & 2 & 1 & 10 & 34 & 25 & 16 & 100 \\
\hline \multirow{2}{*}{$\begin{array}{l}\text { Learning style of } \\
\text { Visual-Verbal (VV4) }\end{array}$} & \multicolumn{7}{|c|}{ Inconvenient versus Ergonomic-5 } & \multirow[b]{2}{*}{ Total } \\
\hline & Very old & Old & Less old & Not modern & $\begin{array}{c}\text { Less } \\
\text { modern }\end{array}$ & Modern & $\begin{array}{c}\text { Very } \\
\text { attractive }\end{array}$ & \\
\hline $\begin{array}{l}\text { I like teacher who put a } \\
\text { lot of diagrams on the } \\
\text { board }\end{array}$ & 1 & & 3 & 8 & 15 & 22 & 19 & 68 \\
\hline $\begin{array}{l}\text { I like teacher who spend } \\
\text { a lot of time explaining }\end{array}$ & 2 & & 2 & 5 & 11 & 6 & 6 & 32 \\
\hline Total & 3 & & 5 & 13 & 26 & 28 & 25 & 100 \\
\hline
\end{tabular}

(ii) Design no. 2.

(1) Most of the students who confessed doing something important first and other things later (Q4), they feel that Design no. 2 is mostly "lame".

(2) The students who feel that others think about he or she as the person who organizes things well (Q5) and fulfills the priority of work by the important things first and other things later (Q4), they identified the proposed Design no. 2 as "dislike".

(3) Most students who identified Design no. 2 is as "unattractive" and most of them are the students who identified themselves as the persons who like read the book that say things in creative way (SI7). (iii) Design no. 4.

Most of the students identified Design no. 4 is as "fragile" (66 out of 100 students), "unattractive" (53 out of 100 students), "old fashion" (55 out of 100 students), and "lame" (58 out of 100). Most of them are the students who identified themselves as the persons who prefer the way of writers telling the story in the books with saying things in creative, interesting ways (SI7).

(iv) Design no. 5.

(1) The students tend to identify Design no. 5 "cool" rather than "lame," especially for students who thinking they are changing the way doing the 
TABLE 22: The interpretation of Design no. 6 versus the the students' Preferences related to the entertainment (VV10). (Based on Kansei words of Fragile-Durable, Unattractive-Attractive, Lame-Cool, Unintuitive-Intuitive, and Inconvenient-Ergonomic).

\begin{tabular}{|c|c|c|c|c|c|c|c|c|}
\hline \multirow{2}{*}{$\begin{array}{l}\text { Learning style of } \\
\text { Visual-Verbal (VV10) }\end{array}$} & \multicolumn{7}{|c|}{ Fragile versus Durable-6 } & \multirow[b]{2}{*}{ Total } \\
\hline & Very fragile & Fragile & Less fragile & Not durable & Less durable & Durable & $\begin{array}{c}\text { Very } \\
\text { durable }\end{array}$ & \\
\hline $\begin{array}{l}\text { For entertainment, I } \\
\text { would rather watch } \\
\text { television }\end{array}$ & 1 & 7 & 6 & 20 & 15 & 20 & 8 & 77 \\
\hline $\begin{array}{l}\text { For entertainment, I } \\
\text { would rather read a book }\end{array}$ & 1 & 2 & 5 & 10 & 3 & 1 & 1 & 23 \\
\hline Total & 2 & 9 & 11 & 30 & 18 & 21 & 9 & 100 \\
\hline \multirow{2}{*}{$\begin{array}{l}\text { Learning style of } \\
\text { Visual-Verbal (VV10) }\end{array}$} & \multicolumn{7}{|c|}{ Unattractive versus Attractive- 6} & \multirow[b]{2}{*}{ Total } \\
\hline & $\begin{array}{c}\text { Very } \\
\text { unattractive }\end{array}$ & Attractive & $\begin{array}{c}\text { Less } \\
\text { unattractive }\end{array}$ & $\begin{array}{c}\text { Not } \\
\text { attractive }\end{array}$ & $\begin{array}{c}\text { Less } \\
\text { attractive }\end{array}$ & Attractive & $\begin{array}{c}\text { Very } \\
\text { attractive }\end{array}$ & \\
\hline $\begin{array}{l}\text { For entertainment, I } \\
\text { would rather watch } \\
\text { television }\end{array}$ & 1 & 4 & 8 & 21 & 23 & 13 & 7 & 77 \\
\hline $\begin{array}{l}\text { For entertainment, I } \\
\text { would rather read a book }\end{array}$ & 2 & 2 & 2 & 9 & 6 & 2 & 0 & 23 \\
\hline Total & 3 & 6 & 10 & 30 & 29 & 15 & 7 & 100 \\
\hline \multirow{2}{*}{$\begin{array}{l}\text { Learning style of } \\
\text { Visual-Verbal (VV10) }\end{array}$} & \multicolumn{7}{|c|}{ Lame versus Cool-6 } & \multirow{2}{*}{ Total } \\
\hline & Very lame & Lame & Less lame & Not cool & Less cool & Cool & Very cool & \\
\hline $\begin{array}{l}\text { For entertainment, I } \\
\text { would rather watch } \\
\text { television }\end{array}$ & 2 & 6 & 9 & 17 & 18 & 18 & 7 & 77 \\
\hline $\begin{array}{l}\text { For entertainment, I } \\
\text { would rather read a book }\end{array}$ & 3 & 2 & 2 & 8 & 6 & 2 & 0 & 23 \\
\hline Total & 5 & 8 & 11 & 25 & 24 & 20 & 7 & 100 \\
\hline \multirow{2}{*}{$\begin{array}{l}\text { Learning style of } \\
\text { Visual-Verbal (VV10) }\end{array}$} & \multicolumn{7}{|c|}{ Unintuitive versus Intuitive- 6} & \multirow[b]{2}{*}{ Total } \\
\hline & $\begin{array}{c}\text { Very } \\
\text { unintuitive }\end{array}$ & Unintuitive & $\begin{array}{c}\text { Less } \\
\text { unintuitive }\end{array}$ & $\begin{array}{c}\text { Not } \\
\text { intuitive }\end{array}$ & $\begin{array}{c}\text { Less } \\
\text { intuitive }\end{array}$ & Intuitive & $\begin{array}{c}\text { Very } \\
\text { intuitive }\end{array}$ & \\
\hline $\begin{array}{l}\text { For entertainment, I } \\
\text { would rather watch } \\
\text { television }\end{array}$ & 1 & 4 & 8 & 24 & 18 & 15 & 7 & 77 \\
\hline $\begin{array}{l}\text { For entertainment, I } \\
\text { would rather read a book }\end{array}$ & 1 & 3 & 34 & 10 & 5 & 1 & 0 & 23 \\
\hline Total & 2 & 7 & 11 & 34 & 23 & 16 & 7 & 100 \\
\hline \multirow{2}{*}{$\begin{array}{l}\text { Learning style of } \\
\text { Visual-Verbal (VV10) }\end{array}$} & \multicolumn{7}{|c|}{ Inconvenient versus Ergonomic-6 } & \multirow[b]{2}{*}{ Total } \\
\hline & $\begin{array}{c}\text { Very } \\
\text { inconvenient }\end{array}$ & Inconvenient & $\begin{array}{c}\text { Less } \\
\text { convenient }\end{array}$ & $\begin{array}{c}\text { Not } \\
\text { ergonomic }\end{array}$ & $\begin{array}{c}\text { Less } \\
\text { ergonomic }\end{array}$ & Ergonomic & $\begin{array}{c}\text { Very } \\
\text { ergonomic }\end{array}$ & \\
\hline $\begin{array}{l}\text { For entertainment, I } \\
\text { would rather watch } \\
\text { television }\end{array}$ & 2 & 3 & 9 & 13 & 22 & 17 & 11 & 77 \\
\hline $\begin{array}{l}\text { For entertainment, I } \\
\text { would rather read a book }\end{array}$ & 1 & 3 & 4 & 6 & 8 & 1 & 0 & 23 \\
\hline Total & 3 & 6 & 13 & 9 & 30 & 18 & 11 & 100 \\
\hline
\end{tabular}

job for variety and prefer to arrange objects to be centered and in line (Q6 and Q7).

(2) Most of students who like the teacher to put a lot diagrams on the board (VV4) identified Design no. 5 is as "durable" (92 out of 100 students), "unattractive" (79 out of 100 students), "old fashion" (75 out of 100 students), "lame" ( 79 out of 100 students).
(3) Most of students who identified themselves as the persons who prefer to look over pictures and chart carefully rather than written text (VV3), they prefer Design no. 5. (67 out of 100 students).

(4) The students who prefer to learn concept than facts as it is easier (SI3), they consider Design no. 5 to be their preference or "like" (52 of out 100 students). 
TABLE 23: Correlation between cognitive alert style and the preferences of the 8 designs proposed.

(a)

\begin{tabular}{|c|c|c|c|c|c|c|c|c|c|}
\hline Dislike versus like & Q1 & Q2 & Q3 & $\mathrm{Q} 4$ & Q5 & Q6 & Q7 & Q8 & Q9 \\
\hline 1-Frame Design & & & & & $0.216^{*}$ & & & & \\
\hline 2-Frame Design & & & & $-0.234^{*}$ & & & & & \\
\hline 3-Frame Design & & & & & & & & & \\
\hline 4-Frame Design & & & & & & & & & \\
\hline 5-Frame Design & & & & & & & & & \\
\hline 6-Frame Design & & & & & & & & & \\
\hline 7-Frame Design & & & & & & & & & \\
\hline 8-Frame Design & & & & & & & & & \\
\hline
\end{tabular}

(b)

\begin{tabular}{|c|c|c|c|c|c|c|c|c|}
\hline \multirow{2}{*}{$\begin{array}{l}\text { Cognitive alert } \\
\text { style-Q5 }\end{array}$} & \multicolumn{7}{|c|}{ 1-Frame Design } & \multirow[b]{2}{*}{ Total } \\
\hline & $\begin{array}{l}\text { Very not } \\
\text { preference }\end{array}$ & $\begin{array}{c}\text { Not } \\
\text { preference }\end{array}$ & $\begin{array}{l}\text { Very low } \\
\text { preference }\end{array}$ & $\begin{array}{l}\text { Low } \\
\text { preference }\end{array}$ & Preference & $\begin{array}{c}\text { Strong } \\
\text { preference }\end{array}$ & $\begin{array}{l}\text { Very strong } \\
\text { preference }\end{array}$ & \\
\hline $\begin{array}{l}\text { Other people think } \\
\text { I'm unorganized }\end{array}$ & 4 & 4 & 8 & 5 & 4 & 4 & 1 & 30 \\
\hline $\begin{array}{l}\text { Other people think I } \\
\text { organize things well }\end{array}$ & 6 & 6 & 8 & 10 & 22 & 11 & 7 & 70 \\
\hline Total & 10 & 10 & 16 & 15 & 26 & 15 & 8 & 100 \\
\hline
\end{tabular}

(c)

\begin{tabular}{|c|c|c|c|c|c|c|c|c|}
\hline \multirow{2}{*}{$\begin{array}{l}\text { Cognitive alert } \\
\text { style-Q4 }\end{array}$} & \multicolumn{7}{|c|}{ 2-Frame Design } & \multirow[b]{2}{*}{ Total } \\
\hline & $\begin{array}{l}\text { Very not } \\
\text { preference }\end{array}$ & $\begin{array}{c}\text { Not } \\
\text { preference }\end{array}$ & $\begin{array}{l}\text { Very low } \\
\text { preference }\end{array}$ & $\begin{array}{c}\text { Low } \\
\text { preference }\end{array}$ & Preference & $\begin{array}{c}\text { Strong } \\
\text { preference }\end{array}$ & $\begin{array}{l}\text { Very strong } \\
\text { preference }\end{array}$ & \\
\hline $\begin{array}{l}\text { I do easy things first } \\
\text { and save important } \\
\text { things for later }\end{array}$ & 4 & 5 & 3 & 4 & 2 & 1 & 2 & 21 \\
\hline $\begin{array}{l}\text { I do important things } \\
\text { first and other things } \\
\text { later }\end{array}$ & 28 & 21 & 12 & 8 & 9 & 1 & 0 & 79 \\
\hline Total & 32 & 26 & 15 & 12 & 11 & 2 & 2 & 100 \\
\hline
\end{tabular}

${ }^{*}$ Correlation is significant at the 0.05 level ( 2 tailed).

${ }^{* *}$ Correlation is significant at the 0.01 level ( 2 tailed).

TABLE 24: Correlation between the preferences of design proposed against Sensing-Intuitive learning style.

\begin{tabular}{lccccccc}
\hline & $\begin{array}{c}\text { 1-Frame } \\
\text { Design }\end{array}$ & $\begin{array}{c}\text { 2-Frame } \\
\text { Design }\end{array}$ & $\begin{array}{c}\text { 3-Frame } \\
\text { Design }\end{array}$ & $\begin{array}{c}\text { 4-Frame } \\
\text { Design }\end{array}$ & $\begin{array}{c}\text { 5-Frame } \\
\text { Design }\end{array}$ & $\begin{array}{c}\text { 6-Frame } \\
\text { Design }\end{array}$ & $\begin{array}{c}\text { 7-Frame } \\
\text { Design }\end{array}$ \\
\hline Sensing & & $0.203^{*}$ & & & $0.223^{*}$ \\
Intuitive & & & & & $-0.203^{*}$ \\
\hline
\end{tabular}

${ }^{*}$ Correlation is significant at the 0.05 level (2 tailed).

${ }^{* *}$ Correlation is significant at the 0.01 level ( 2 tailed).

(v) Design no. 6.

(1) Most of students who identified themselves as the persons who prefer to watch the television for entertainment, they identified Design no. 6 as "intuitive" ( 46 out of 100 students), "ergonomic" ( 59 out of 100 students), "durable" (48 out of 100 students), "attractive" (51 out of 100 students), "cool" ( 51 out of 100 students), and "intuitive" (46 out of 100 students).
(2) Towards the Kansei word "lame versus cool", the "visual-verbal" learning style of what the students think about the past (yesterday), they are mostly likely to get "a picture" rather words (VV1). Here, there are 52 out of 100 students who prefer Design no. 6 and most of them are the students that identified themselves as the persons who prefer to look over pictures and chart carefully rather than written text (VV3) as well as identified themselves as the persons 
TABLe 25: (a, b) Correlation between learning style of "Sensing-Intuitive" type versus the preferences of the 8 designs proposed. (c, d) Correlation between learning style of "Visual-Verbal" type versus the preferences of the 8 designs proposed.

(a)

\begin{tabular}{|c|c|c|c|c|c|c|c|c|c|c|c|}
\hline Design & SI-1 & SI-2 & SI-3 & SI- 4 & SI-5 & SI-6 & SI-7 & SI-8 & SI-9 & SI-10 & SI-11 \\
\hline \multicolumn{12}{|l|}{ 1-Frame Design } \\
\hline 2-Frame Design & & & & & & & $-0.283^{* *}$ & & & & \\
\hline 3-Frame Design & & & & & & & & & $-0.200^{*}$ & & \\
\hline 4-Frame Design & & & & & & & $-0.239^{*}$ & & $-0.0216^{*}$ & & \\
\hline 5-Frame Design & & & $0.198^{*}$ & & & & & & & & \\
\hline \multicolumn{12}{|l|}{ 6-Frame Design } \\
\hline \multicolumn{12}{|l|}{ 7-Frame Design } \\
\hline 8-Frame Design & & & & & & & & & & & \\
\hline
\end{tabular}

(b)

\begin{tabular}{|c|c|c|c|c|c|c|c|c|}
\hline \multirow[b]{2}{*}{ Leaning style-SI7 } & \multicolumn{7}{|c|}{ 2-Frame Design } & \multirow[b]{2}{*}{ Tota } \\
\hline & $\begin{array}{c}\text { Very not } \\
\text { preference }\end{array}$ & $\begin{array}{c}\text { Not } \\
\text { preference }\end{array}$ & $\begin{array}{c}\text { Very low } \\
\text { preference }\end{array}$ & $\begin{array}{c}\text { Low } \\
\text { preference }\end{array}$ & Preference & $\begin{array}{c}\text { Strong } \\
\text { preference } \\
\end{array}$ & $\begin{array}{l}\text { Very strong } \\
\text { preference }\end{array}$ & \\
\hline $\begin{array}{l}\text { Clearly say what they } \\
\text { mean }\end{array}$ & 5 & 6 & 3 & 7 & 5 & 1 & 1 & 28 \\
\hline $\begin{array}{l}\text { Say things in creative, } \\
\text { interesting way }\end{array}$ & 27 & 20 & 12 & 5 & 6 & 1 & 1 & 72 \\
\hline Total & 32 & 26 & 15 & 12 & 11 & 2 & 2 & 100 \\
\hline \multirow[b]{2}{*}{ Leaning style-SI3 } & \multicolumn{7}{|c|}{ 5-Frame Design } & \\
\hline & $\begin{array}{l}\text { Very not } \\
\text { preference }\end{array}$ & $\begin{array}{c}\text { Not } \\
\text { preference }\end{array}$ & $\begin{array}{l}\text { Very low } \\
\text { preference }\end{array}$ & $\begin{array}{c}\text { Low } \\
\text { preference }\end{array}$ & Preference & $\begin{array}{c}\text { Strong } \\
\text { preference }\end{array}$ & $\begin{array}{l}\text { Very strong } \\
\text { preference }\end{array}$ & Total \\
\hline $\begin{array}{l}\text { Clearly say what they } \\
\text { mean }\end{array}$ & 1 & & 3 & 8 & 12 & 10 & 9 & 43 \\
\hline $\begin{array}{l}\text { Say things in creative, } \\
\text { interesting way }\end{array}$ & 1 & & 1 & 3 & 16 & 21 & 15 & 57 \\
\hline Total & 2 & & 4 & 11 & 28 & 31 & 24 & 100 \\
\hline
\end{tabular}

(c)

\begin{tabular}{|c|c|c|c|c|c|c|c|c|c|c|c|}
\hline Design & VV-1 & VV-2 & VV-3 & VV-4 & VV-5 & VV-6 & VV-7 & VV8 & VV-9 & VVI-10 & VV-11 \\
\hline \multicolumn{12}{|l|}{ 1-Frame Design } \\
\hline \multicolumn{12}{|l|}{ 2-Frame Design } \\
\hline 3-Frame Design & & & & & & & & $-0.256^{*}$ & $-0.270^{* *}$ & & \\
\hline 4-Frame Design & & & & & & & & & $-0.241^{*}$ & & \\
\hline 5-Frame Design & & & $-0.238^{*}$ & & & & & & & & \\
\hline 6-Frame Design & & $-0.207^{*}$ & $-0.228^{*}$ & & & & & & & $-0.281^{* *}$ & \\
\hline \multicolumn{12}{|l|}{ 7-Frame Design } \\
\hline 8-Frame Design & & & & & & & & & & & \\
\hline
\end{tabular}

(d)

\begin{tabular}{|c|c|c|c|c|c|c|c|c|}
\hline \multirow[b]{2}{*}{ Leaning style-VV3 } & \multicolumn{7}{|c|}{ 5-Frame design } & \multirow[b]{2}{*}{ Total } \\
\hline & $\begin{array}{c}\text { Very not } \\
\text { preference }\end{array}$ & $\begin{array}{c}\text { Not } \\
\text { preference }\end{array}$ & $\begin{array}{l}\text { Very low } \\
\text { preference }\end{array}$ & $\begin{array}{c}\text { Low } \\
\text { preference }\end{array}$ & Preference & $\begin{array}{c}\text { Strong } \\
\text { preference }\end{array}$ & $\begin{array}{l}\text { Very strong } \\
\text { preference }\end{array}$ & \\
\hline \multicolumn{9}{|c|}{$\begin{array}{l}\text { In a book with lots of } \\
\text { pictures and charts, I like } \\
\text { to }\end{array}$} \\
\hline $\begin{array}{l}\text { look over pic. and } \\
\text { chart carefully }\end{array}$ & 0 & & 2 & 9 & 22 & 24 & 21 & 78 \\
\hline focus on written text & 2 & & 2 & 2 & 6 & 7 & 3 & 22 \\
\hline Total & 2 & & 4 & 11 & 28 & 31 & 24 & 100 \\
\hline
\end{tabular}


(d) Continued.

\begin{tabular}{|c|c|c|c|c|c|c|c|c|}
\hline \multirow[b]{2}{*}{ Leaning Style-VV3 } & \multicolumn{7}{|c|}{ 6-Frame Design } & \multirow[b]{2}{*}{ Total } \\
\hline & $\begin{array}{l}\text { Very not } \\
\text { preference }\end{array}$ & $\begin{array}{l}\text { Not } \\
\text { preference }\end{array}$ & $\begin{array}{l}\text { Very low } \\
\text { preference }\end{array}$ & $\begin{array}{l}\text { Low } \\
\text { preference }\end{array}$ & Preference & $\begin{array}{l}\text { Strong } \\
\text { preference }\end{array}$ & $\begin{array}{l}\text { Very strong } \\
\text { preference }\end{array}$ & \\
\hline \multicolumn{9}{|c|}{$\begin{array}{l}\text { With lots of pictures and } \\
\text { charts, I like to }\end{array}$} \\
\hline $\begin{array}{l}\text { look over pic. and } \\
\text { chart carefully }\end{array}$ & 0 & 5 & 12 & 16 & 24 & 14 & 7 & 78 \\
\hline focus on written text & 2 & 1 & 8 & 3 & 4 & 3 & 1 & 22 \\
\hline \multirow[t]{2}{*}{ Total } & 2 & 6 & 20 & 19 & 28 & 17 & 8 & 100 \\
\hline & \multicolumn{7}{|c|}{ 6-Frame Design } & \\
\hline Leaning Style-VV1 & $\begin{array}{c}\text { Very not } \\
\text { preference }\end{array}$ & $\begin{array}{c}\text { Not } \\
\text { preference }\end{array}$ & $\begin{array}{c}\text { Very low } \\
\text { preference }\end{array}$ & $\begin{array}{c}\text { Low } \\
\text { preference }\end{array}$ & Preference & $\begin{array}{c}\text { Strong } \\
\text { preference }\end{array}$ & $\begin{array}{l}\text { Very strong } \\
\text { preference }\end{array}$ & Total \\
\hline \multicolumn{9}{|l|}{$\begin{array}{l}\text { When I think about } \\
\text { what I did yesterday, I } \\
\text { most likely to get }\end{array}$} \\
\hline a picture & 1 & 5 & 16 & 15 & 25 & 15 & 8 & 85 \\
\hline words & 1 & 1 & 4 & 4 & 3 & 2 & 0 & 15 \\
\hline \multirow[t]{2}{*}{ Total } & 2 & 6 & 20 & 19 & 28 & 17 & 8 & 100 \\
\hline & \multicolumn{7}{|c|}{ 6-Frame Design } & \\
\hline Leaning style-VV9 & $\begin{array}{l}\text { Very not } \\
\text { preference }\end{array}$ & $\begin{array}{c}\text { Not } \\
\text { preference }\end{array}$ & $\begin{array}{c}\text { Very low } \\
\text { preference }\end{array}$ & $\begin{array}{c}\text { Low } \\
\text { preference }\end{array}$ & Preference & $\begin{array}{c}\text { Strong } \\
\text { preference }\end{array}$ & $\begin{array}{l}\text { Very strong } \\
\text { preference }\end{array}$ & Total \\
\hline \multicolumn{9}{|c|}{$\begin{array}{l}\text { When I meet people at a } \\
\text { party, I am more likely to } \\
\text { remember what }\end{array}$} \\
\hline they looked like & 1 & 4 & 11 & 12 & 23 & 14 & 5 & 70 \\
\hline they said & 1 & 2 & 9 & 7 & 5 & 3 & 3 & 30 \\
\hline Total & 2 & 6 & 20 & 19 & 28 & 17 & 8 & 100 \\
\hline
\end{tabular}

${ }^{*}$ Correlation is significant at the 0.05 level ( 2 tailed).

${ }^{*}{ }^{*}$ Correlation is significant at the 0.01 level ( 2 tailed).

who more likely to remember someone as what they looked like when meeting people at a party (VV9) (42 students).

Based on the aforementioned, in order to improve the effectiveness of teaching and learning process, there are several suggestions given, such as

(a) alternate efforts are needed for exploring the advantages of every learning style which is implemented in the class for improving the teaching and learning by gathering detailed materials as an education referral, especially with pictures, diagrams, graphs, or maps;

(b) the implementation of educational method should triggers the students who are using spectacles to find themselves in detailed work and memorizing tasks. Since they prefer to use the established methods in solving the problems, let them learn the fact by mediating and facilitating them to the activities with hands-on work. Particularly, to something that having direct connection to "the real world." Here, the lecturer should act as someone who makes them remember his/her existence which trigger them to repeat all the steps and check the work carefully when they are doing the calculation.

Since the study carried out was limited to manufacturing engineering students, further studies are required to validate this finding. Here, the spectacles designs proposed also should be broadened with more varieties of designs. In addition, the involvement of larger respondents (another faculty), the study of lecturer's preferences styles in teaching, and the use of others learning style measurement (i.e., Dunn and Dunn, etc., $[1,28]$ ) are, therefore, needed to be considered for teaching and learning. This was as what highlighted by Curry [29] about the failure to identify the style characteristics that were most relevant to learners and instructional setting as a major concern in the field. Therefore, as stated by Cassidy [30], deliberation and documentation of the choice model are needed which reflects a broad awareness of the field and which allows for results and outcomes to be dealt with within a clear conceptual framework. 


\section{Appendix}

Cognitive Alert Style

Q1. I'm proud of the creativity of my work I'm proud of the thoroughness of my work

Q2.

When I take a "break" I relax and do nothing

When I take a "break" I find something different to do

Q3. I don't think about the time when I work I plan out my time when doing work

I do easy things first and save important things for later

I do important things first and other things later

Q5. Other people think I'm unorganized Other people think I organize things well

Q6. I arrange objects so they are off-center and angled

I arrange objects to be centered and in line

Q7. I change the way I do a job, for variety When one way works well, I don't change it

Q8. I'm usually late

I'm usually early

Q9. Where I put things depends on what I'm doing

I put each thing in a particular place.

Index Learning Style (Felder and Soloman questions for perception and input dimension of learning style).

SI1. I would rather be considered $\square$ Realistic $\square$ Innovative

SI2. If I were a teacher, I would rather teach a course

$\square$ That deals with facts and real life situations

$\square$ That deals with ideas and theories

SI3. I find it easier

$\square$ To learn facts $\square$ To learn concepts

SI4. In reading nonfiction, I prefer

$\square$ Something that teaches me new facts or tells me how to do something

$\square$ Something that gives me new ideas to

think about.

SI5. I prefer the idea of

$\square$ Certainty $\square$ Theory

SI6. I am more likely to be considered

$\square$ Careful about the details of my work

$\square$ Creative about how to do my work

SI7. When I am reading for enjoyment, I like writers to

$\square$ Clearly say what they mean

SI8. $\square$ Say things in creative, interesting ways.

When I have to perform a task, I prefer to

$\square$ Master one way of doing it $\square$ Come up with new ways of doing it

SI9. I consider it higher praise to call someone

$\square$ Sensible $\square$ Imaginative

SI10. I prefer courses that emphasize

$\square$ Concrete material (facts, data)

$\square$ Abstract material (concepts, theories)

SI11. When I am doing long calculations

$\square$ I tend to repeat all my steps and check my work carefully

$\square$ I find checking my work tiresome and have to force myself to do it.

VV1. When I think about what I did yesterday, I

am most likely to get

$\square$ A picture $\square$ Words

VV2. I prefer to get new information in

$\square$ Pictures, diagrams, graphs, or maps

$\square$ Written directions or verbal information

VV3. In a book with lots of pictures and charts, I am likely to

$\square$ Look over the pictures and charts carefully

$\square$ Focus on the written text

VV4. I like teachers

$\square$ Who put a lot of diagrams on the board

$\square$ Who spend a lot of time explaining

VV5. I remember best

$\square$ What I see $\square$ What I hear

VV6. When I get directions to a new place, I prefer $\square$ A map $\square$ Written instructions

VV7. When I see a diagram or sketch in class, I am most likely to remember

$\square$ The picture

$\square$ What the instructor said about it

VV8. When someone is showing me data, I prefer

$\square$ Charts or graphs

$\square$ Text summarizing the results

VV9. When I meet people at a party, I am more

likely to remember

$\square$ What they looked like

$\square$ What they said about themselves

VV10. For entertainment, I would rather

$\square$ Watch television $\square$ Read a book

VV11. I tend to picture places I have been

$\square$ Easily and fairly accurately

$\square$ With difficulty and without much detail.

\section{References}

[1] R. S. Dunn and K. J. Dunn, "Learning styles/teaching styles: should they.....can they. . .be matched?" Educational Leadership, pp. 238-244, 1979.

[2] N. F. Horn, "Esophoria and exophoria in relation to personality," Senior Honors Projects Paper no. 213, 2011, http://digitalcommons.uri.edu/srhonorsprog/213.

[3] C. E. Cornett, What You Should Know about Teaching and Learning Styles, Phi Delta Kappa Educational Foundation, Bloomington, India, 1983.

[4] E. S. Smith, "Learning styles: a holistic approach," Journal of European Industrial Training, vol. 20, no. 7, pp. 29-36, 1996. 
[5] H. Pashler, M. McDaniel, D. Rohrer, and R. Bjork, "Learning styles concepts and evidence," Psychological Science in the Public Interest, vol. 9, no. 3, pp. 105-119, 2009.

[6] A. F. Grasha, "Using traditional versus naturalistic approaches to assessing learning styles in college teaching," Journal on Excellence in College Teaching, vol. 1, pp. 23-38, 1990.

[7] J. E. Dyer, "Teaching to Different Learning Styles. UF IFAS Extension," no. WC083, 2008, http://edis.ifas.ufl.edu/wc083.

[8] R. M. Felder and B. A. Soloman, "Learning Styles and Strategies," 1999, http://csl.cofc.edu/documents/study-skills/onlinelibrary/learning_styles/inventory_of_learning_styles_characteristics_of_types_of_learners.pdf.

[9] R. E. Miller, "Student performance: conduct and behavior concerns," International Journal of Teaching and Learning in Higher Education, vol. 21, no. 2, pp. 248-251, 2009.

[10] R. M. Felder and R. Brent, "Understanding student differences," Journal of Engineering Education, vol. 94, no. 1, pp. 57-72, 2005.

[11] J. Choi and S. Sardar, "An empirical investigation of the relationships among cognitive abilities, cognitive style, and learning preferences in students enrolled in specialized degree courses at a Canadian college," The Canadian Journal for the Scholarship of Teaching and Learning, vol. 2, no. 1, 2011.

[12] A. Gregoroc, Gregorc Style Delineator: Development, Technical, and Administration Manual, Gregorc Associates, Columbia, Conn, USA, 1982.

[13] R. Dunn and S. A. Griggs, Practical Approaches to Using Learning Styles in Higher Education, Bergin \& Garvey, Westport, Conn, USA, 2000.

[14] A. Duff, E. Boyle, K. Dunleavy, and J. Ferguson, "The relationship between personality, approach to learning and academic performance," Personality and Individual Differences, vol. 36, no. 8, pp. 1907-1920, 2004.

[15] L. Mariani, "Learning styles: an approach to individual differences," in Learning Paths-Tante Vie Per Imprare. British Council, Milan Conference, pp. 147-153, 1995, http://www.learningpaths.org/papers/stylesanddifferences.pdf.

[16] G. Pask, "Styles and strategies of learning," British Journal of Education. Psychology, vol. 46, pp. 128-148, 1976.

[17] M. Heenaye, B. A. Gobin, and N. A. M. Khan, "Analysis of Felder-Soloman index of learning styles of students from management and engineering at the University of Mauritius," Journal of Education and Vocational Research, vol. 3, no. 8, pp. 244-249, 2012.

[18] R. M. Felder and L. K. Silverman, "Learning styles and teaching styles in engineering education," Engineering Education, vol. 78, no. 7, pp. 674-681, 1988

[19] J. F. Glass and G. P. Muthu, "Learning and individual differences: a systems approach," in Proceedings of HERDSA Annual International Conference, Melbourne, Australia, July 1999.

[20] L. D. Crane, The Alert Scale of Cognitive Style, Western Michigan University, Kalamazoo, Mich, USA, 1989.

[21] M. Bernasconi, C. Choirat, and R. Seri, "The analytic hierarchy process and the theory of measurement," Management Science, vol. 56, no. 4, pp. 699-711, 2010.

[22] M. Nagamachi, "Perspectives of Kansei engineering/ Kansei ergonomics," in Proceedings of International Conference on Human-Computer Interaction, pp. 315-319, Singapore, 2001.

[23] S. H. Lee, A. Harada, and P. J. Stappers, "Pleasure with products: design based on Kansei," in Pleasure with Products: Beyond Usability, W. S. Green, Ed., chapter 16, pp. 219-230, Taylor \& Francis, Abingdon, UK, 2000.
[24] C. Wei, M. Y. Ma, and Y. C. Lin, "Applying Kansei engineering to decision making in fragrance form design," in Intelligent Decision Technologies, vol. 10 of Smart Innovation, Systems and Technologies, pp. 85-94, 2011.

[25] T. L. Saaty, Fundamentals of Decision Making and Priority Theory with the Analytic Hierarchy Process, RWS Publications, Pittsburgh, Pa, USA, 1994.

[26] P. R. Drake, "Using the analytic hierarchy process in engineering education," International Journal of Engineering Education, vol. 14, no. 3, pp. 191-196, 1998.

[27] H. Lee, S. J. Lou, R. C. Shuh, and K. H. Tse, "An AHPbased analysis of network knowledge management platforms for elementary school students," The Turkish Online Journal of Educational Technology, vol. 10, no. 4, pp. 52-59, 2011.

[28] R. Dunn and K. Dunn, Teaching Students through Their Individual Learning Styles, Reston Publishing, Reston, Va, USA, 1978.

[29] L. Curry, "Patterns of learning styles across selected medical specialities," Educational Psychology, vol. 11, pp. 247-278, 1991.

[30] S. Cassidy, "Learning styles: an overview of theories, models, and measures," Educational Psychology, vol. 24, no. 4, pp. 419444, 2004. 

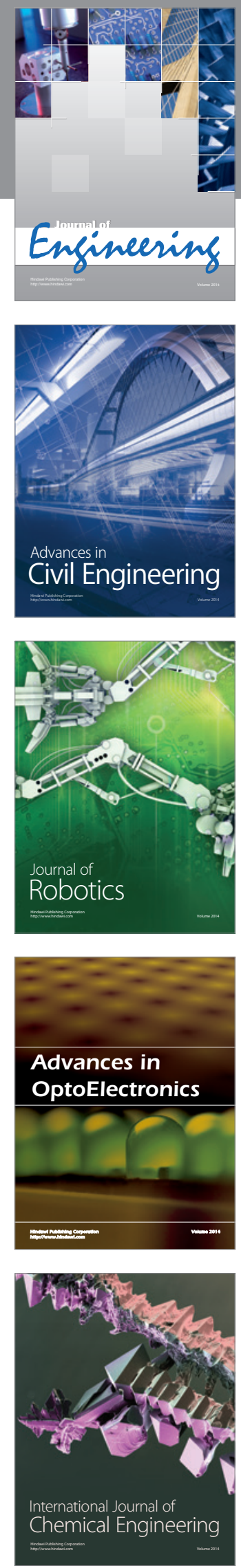

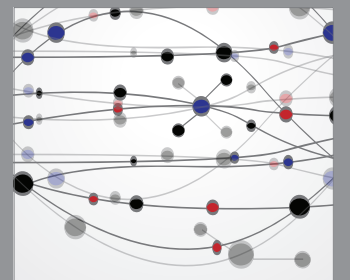

The Scientific World Journal
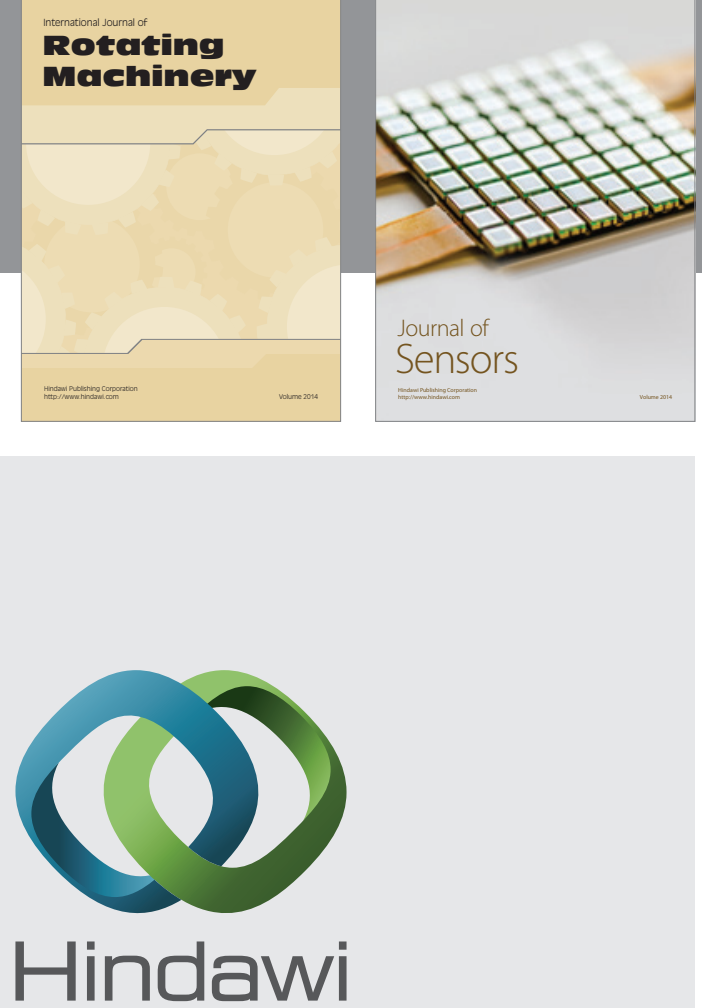

Submit your manuscripts at http://www.hindawi.com
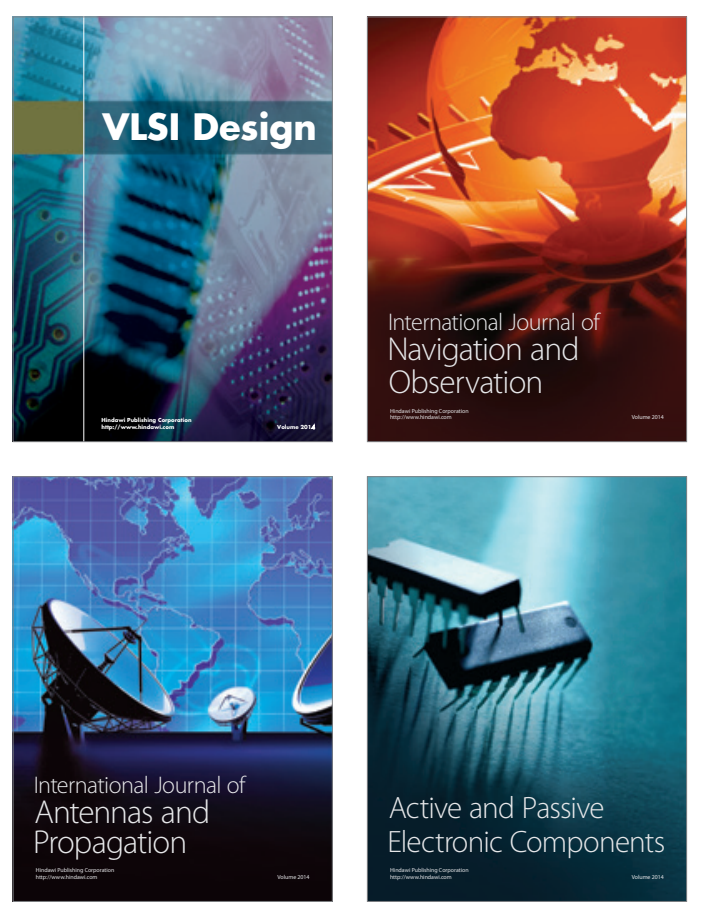
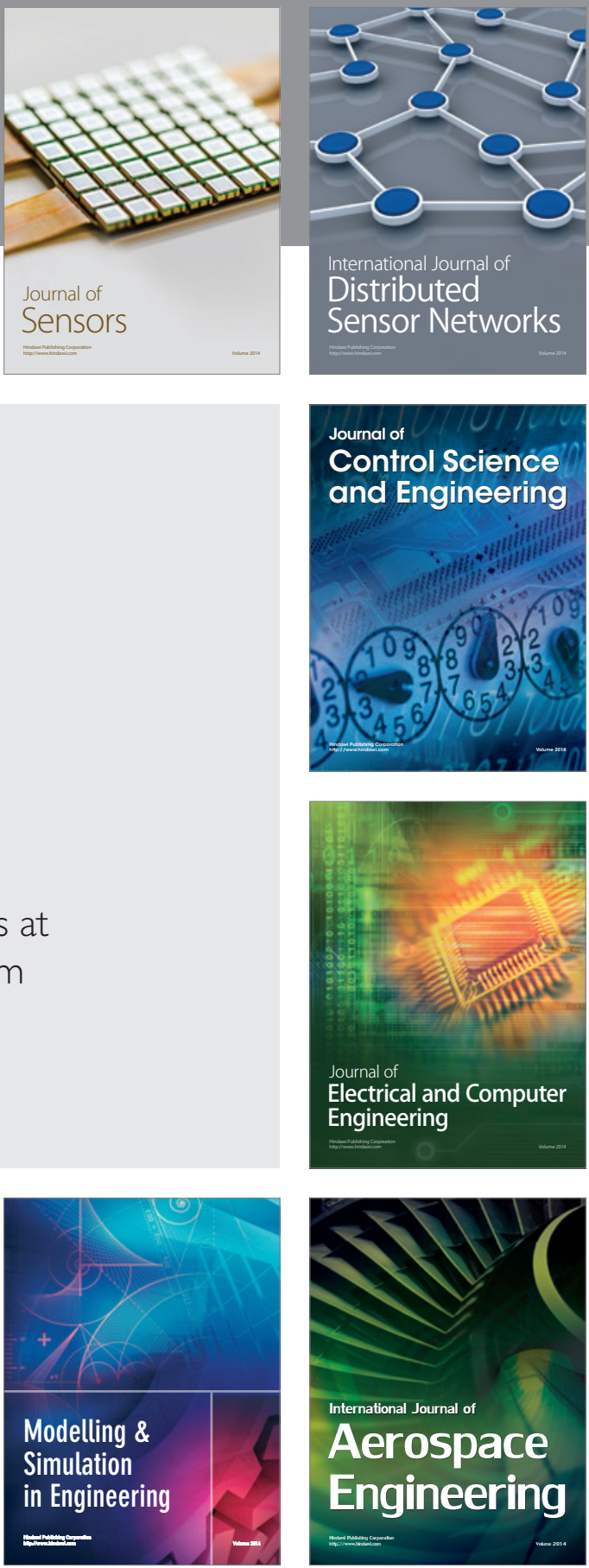

Journal of

Control Science

and Engineering
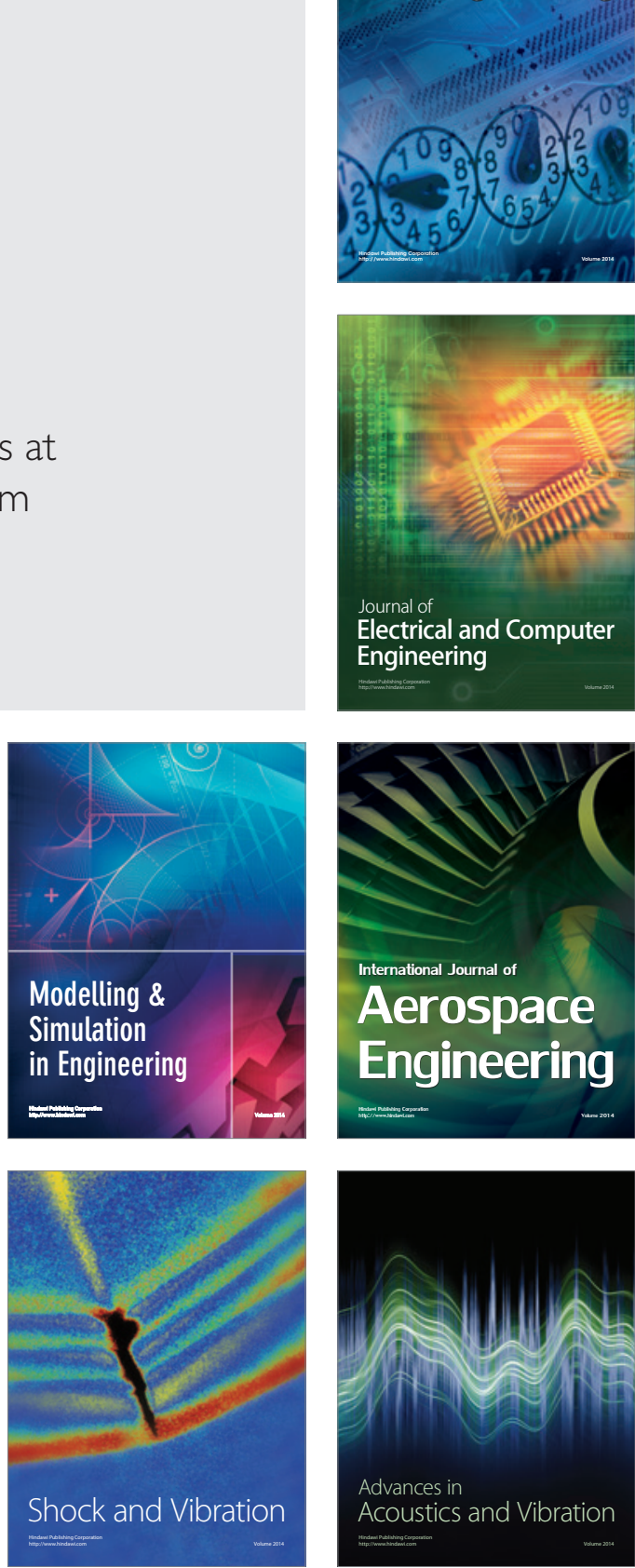